\title{
Reproductive Biology of the Thumbprint Emperor, Lethrinus harak (Forsskal 1775), using histological ultra-structural characteristic in gonads along Sudanese Coastal Waters
}

\author{
Badr Eldinn KH, Adam ${ }^{1 *}$; Sheikheldin M. Elamin ${ }^{1}$; and Salah Eldeen Y.M. Habiballah ${ }^{1}$ \\ 1. Department of Fisheries, Faculty of Marine Sciences and Fisheries, Red Sea University
}

\begin{abstract}
Lethrinus harak (Forsskal 1775) are very common species of the family Lethrinidae in Sudanese Red Sea Coast. Some aspects of the reproductive biology and histology of the gonads of Lehtrinus harak were studied between 2008 and 2009. The present study described six maturity stages for gonad development based on external features and histological study of males/females. Males of Lethrinus harak attain maturity stages at a relatively bigger size than females (at $22.5 \mathrm{~cm}$ for males and $21.7 \mathrm{~cm}$ for females). Lethrinus harak has a prolonged spawning season extending from October to April with peaks in April.
\end{abstract}

Keywords: Lethrinus harak, Reproduction, histology, Abu Hashish, Red Sea

DOI: $10.7176 / \mathrm{JBAH} / 9-4-10$

\section{Introduction}

The study of reproduction and egg production increases our knowledge about the state of a stock and improves standard assessments of many commercially valuable fish species. Lethrinus harak belongs to Family lethrinidae which is one of the commercially important fish groups along the Sudanese Red Sea Coast and widely distributed in Sudanese Red Sea Coast. There are at least four species of the genus Lethrinus common in the Sudanese waters, all of which come under the common Arabic name of Sha'oor, and are one of the most common local commercial fishes and are found throughout the year Abu Gideiri (1984).

There are no biological studies in detail such as studying reproduction and management of fishing in most fishes of Red Sea especially Sudanese Coast. Therefore, this study is an important matter. The aim of this study to collected main base line information on reproductive performance of Lethrinus harak during development in order to investigate the reproductive biology of $L$. harak, including its spawning season, gonad maturity stages, sex ratio, and the size at which $50 \%$ of fish attain first sexual maturity which a future support mariculture and on fisheries management. Hilborn. et al. (1992) and Pauly (1994) reported that growth and mortality model parameter estimates are required for analytical fisheries management.

Hunter et al., (1992) reported that description of reproductive strategies and the assessment of fecundity is fundamental topics in the study of the biology and population dynamics of fish species. Studies on reproduction, including the assessment of size at maturity, fecundity, duration of the reproductive season, daily spawning behaviour and spawning fraction, permit quantification of the reproductive capacity of individual fish. (Kraus, et al., 2002). Filho, (1989) reported that knowledge about the gonadal development of marine fish species is important information to maintain the fishery stocks. The data required to provide such information is typically gathered through the examination and classification of gonads into developmental stages so that parameters such as reproductive period, spawning frequency, size at sexual maturity and sex ratios can be determined. Many studies have been conducted on the genus Lethrinus such as some aspect of the reproductive biology of Lethrinus harak (Ntiba, 1995; Kulmiye et al., 2002and Ebisawa, 2006); histological studies on Lethrinus nebulosus (Loubens,1980); size and age at sexual maturity (Hilomen, 1997 and Lassi, 2003) and some biological aspects of Lethrinus mahsena (Abu Degoon, 2005).

\section{Material and Methods}

\section{Collection of specimen:}

Total of 358 specimens of Lethrinus harak was collected monthly and randomly from the Fish Commercial Centre at Abu Hashish Fish Central Market-Port Sudan during the period from June 2008 to May 2009 The total length (TL), was measured to the nearest $0.1 \mathrm{~cm}$ and the total weight (TW), and gonad weight (GW) were weighed to the nearest 0.01 grams in an electronic balance and age estimates using the scales. 


\section{Reproduction:}

Reproduction information were obtained through the examination of the gonad of Lethrinus harak fish.

\section{Length and age at First Maturity:}

The length at first maturity was defined at the length at which fish attain maturity. Stage (IV) was considered as the mature stage to enable determination of the minimum size at which fish attain sexual maturity. It was estimated according to Soondron et al. (1998).

\section{The Percentage of Mature Fish:}

The Percentage of Mature Fish (\%MF) was a determination for the combined sexes of the stage (IV and V) using the following equation:

\section{MF\% $=[$ Number of mature fish /Total number of in the sample $] \times 100$ \\ Histological processing:}

Whole gonads removed from each individual were blotted dry, weighed to the nearest $0.001 \mathrm{~g}$, sexed and staged macroscopically, and immediately fixed in Bouin's solution for 24 hours for histological processing. Sections of gonads embedded with paraffin wax were mounted on glass slides and stained with Haematoxylin and Eosin (Harris, 1900). These sections were viewed under a high powered microscope to confirm macroscopic sexes and stages.

\section{Results}

\section{Maturity stages:}

The gonads of $358 \mathrm{~L}$. harak individuals were examined. These individuals ranged in size from 14.3 to $35.7 \mathrm{~cm}$. The description of maturity stages of Lethrinus harak in Table 1, while mature ovaries and testes are shown in Fig. 1 and 2.

Table 1. Description of maturity stages of Lethrinus harak gonads.

\begin{tabular}{|c|c|c|}
\hline & Testes & Ovary \\
\hline Maturity & External Feature & External Feature \\
\hline Stage 1 Immature & $\begin{array}{l}\text { Long, slender and thread like translucent } \\
\text { structures occupying about } 33 \% \text { of the } \\
\text { abdominal cavity }\end{array}$ & $\begin{array}{l}\text { Long, slender and thread like } \\
\text { structures, red colour also occupying } \\
33 \% \text { of the abdominal cavity }\end{array}$ \\
\hline Developing & $\begin{array}{l}\text { Ribbon-like structures slightly bigger } \\
\text { than stage } 1 \text {, grayish-white in colour } \\
\text { occupying } 50 \% \text { of cavity }\end{array}$ & $\begin{array}{l}\text { Firm and like with slight increase in } \\
\text { size pink in colour and } 50 \% \text { of cavity } \\
\text { oocytes not discernible. }\end{array}$ \\
\hline Maturing & $\begin{array}{l}\text { Broad and thick dark white in in colour, } \\
\text { blood vessels visible externally milt } \\
\text { oozes out from cut surfaces and } \\
\text { occupying } 70 \% \text { of the abdominal cavity }\end{array}$ & $\begin{array}{l}\text { Board and thick occupying } 70 \% \text { of the } \\
\text { abdominal cavity red or reddish } \\
\text { brown. Cavity red or reddish brown. } \\
\text { ernally. Oocytes visible through the } \\
\text { ovary wall }\end{array}$ \\
\hline Ripe & $\begin{array}{l}\text { Further increase size occupying } 90 \% \text { of } \\
\text { the abdominal cavity White in colour. } \\
\text { Milt oozes out on slight pressure. }\end{array}$ & $\begin{array}{l}\text { Distended and occupying } 90 \% \text { of the } \\
\text { abdominal cavity. Vessels } \\
\text { disappearing, oocytes can be seen } \\
\text { clearly through the ovary wall. }\end{array}$ \\
\hline Running & $\begin{array}{l}\text { Fully distended, occupying almost all the } \\
\text { abdominal cavity exudes milt on slight } \\
\text { pressure. }\end{array}$ & $\begin{array}{l}\text { Fully distended with granular surface } \\
\text { occupying almost all the abdominal } \\
\text { cavity. }\end{array}$ \\
\hline Spent & $\begin{array}{l}\text { Shrunken and flaccid, walls are harder } \\
\text { and wrinkled. No milt oozes out on } \\
\text { pressure and blood vessels visible } \\
\text { externally. }\end{array}$ & $\begin{array}{l}\text { Ovary is not fully empty. Residual } \\
\text { oocytes present flaccid and red in } \\
\text { colour and Ovary wall is thick. }\end{array}$ \\
\hline
\end{tabular}




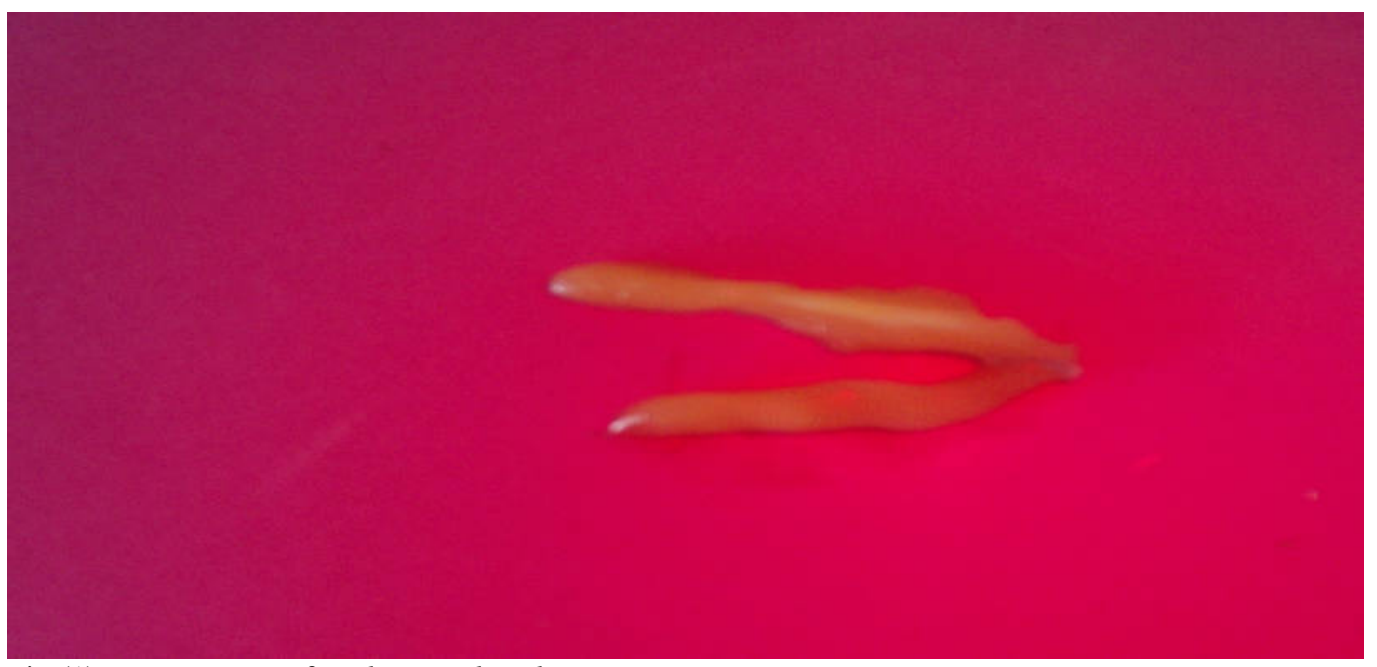

Fig (1) mature ovary of Lethrinus harak

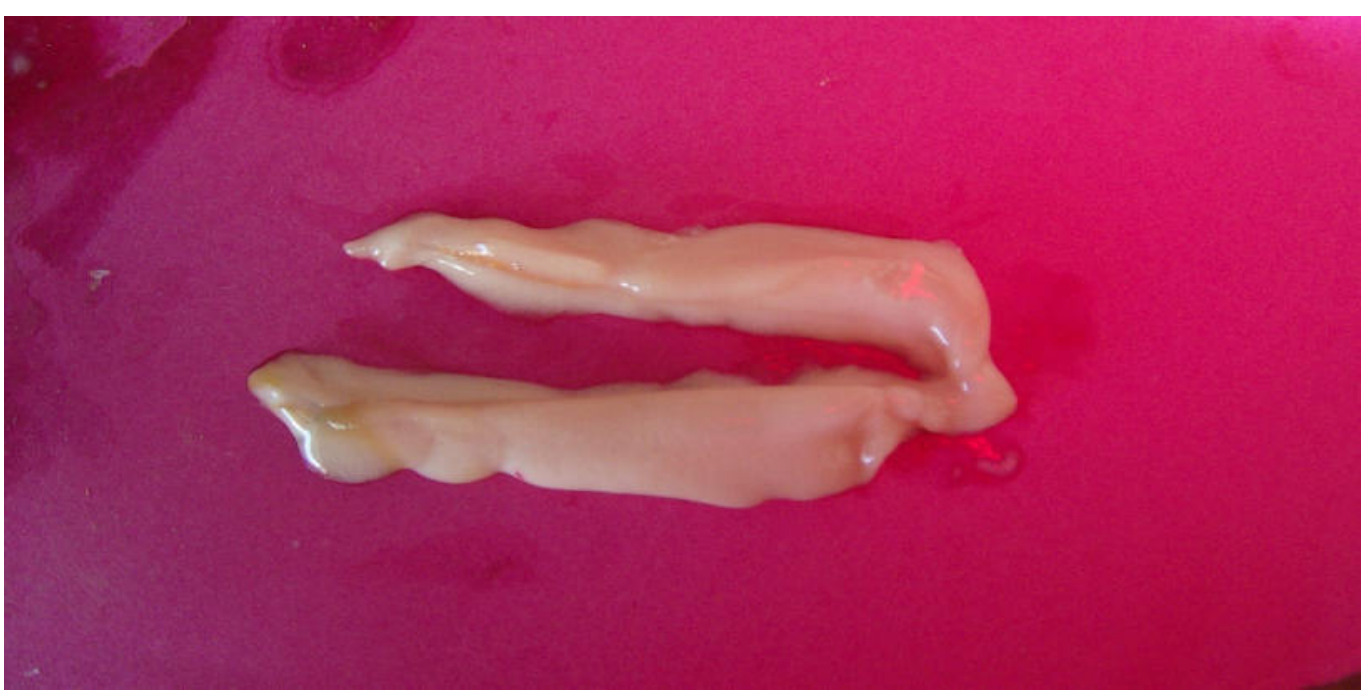

Fig (2) mature testes of Lethrinus harak

\section{Length and age at first sexual maturity:}

To determine the average size at which 50\% of Lethrinus harak males and females attain first sexual maturity (fish in stage 2 of gonad development and above were considered mature). Fish belonging to this species attains their first sexual maturity at $22.5 \mathrm{~cm}$ for males and $21.7 \mathrm{~cm}$ for females (Table 2 and Fig. 3).

Table 2. Age, mean length and percentage of mature fish used to determine length and age at first maturity $\left(\mathrm{L}_{\mathrm{T} 50}\right)$ for Lethrinus harak.

\begin{tabular}{|c|c|c|c|c|c|c|c|c|c|}
\hline \multicolumn{9}{|c|}{ Females } & \multicolumn{4}{c|}{ Males } \\
\hline $\begin{array}{c}\text { Age } \\
\text { group }\end{array}$ & $\begin{array}{c}\text { Mean } \\
\text { length } \\
\text { (cm) }\end{array}$ & Frequency & $\begin{array}{c}\text { Cumulative } \\
\text { Frequency }\end{array}$ & $\begin{array}{c}\text { \% of } \\
\text { Mature } \\
\text { fish }\end{array}$ & $\begin{array}{c}\text { Age } \\
\text { group }\end{array}$ & $\begin{array}{c}\text { Mean } \\
\text { length } \\
\text { (cm) }\end{array}$ & Frequency & $\begin{array}{c}\text { Cumulative } \\
\text { frequency }\end{array}$ & $\begin{array}{c}\text { \% of } \\
\text { Mature } \\
\text { fish }\end{array}$ \\
\hline I & 14.83 & 0 & 0 & 0.00 & I & 14.3 & 0 & 0 & 0.00 \\
\hline II & 19.96 & 26 & 26 & 19.70 & II & 20.16 & 9 & 9 & 7.56 \\
\hline III & 23.39 & 78 & 104 & 78.79 & III & 23.5 & 75 & 84 & 70.59 \\
\hline IV & 27.41 & 17 & 121 & 91.67 & IV & 27.2 & 21 & 105 & 88.24 \\
\hline V & 35.04 & 11 & 132 & 100.00 & V & 35.7 & 14 & 119 & 100. \\
\hline Total & & 132 & & & & & 119 & & \\
\hline
\end{tabular}

\footnotetext{
Age $\mathrm{I}=0+$, Age $\mathrm{II}=1+$, etc
} 


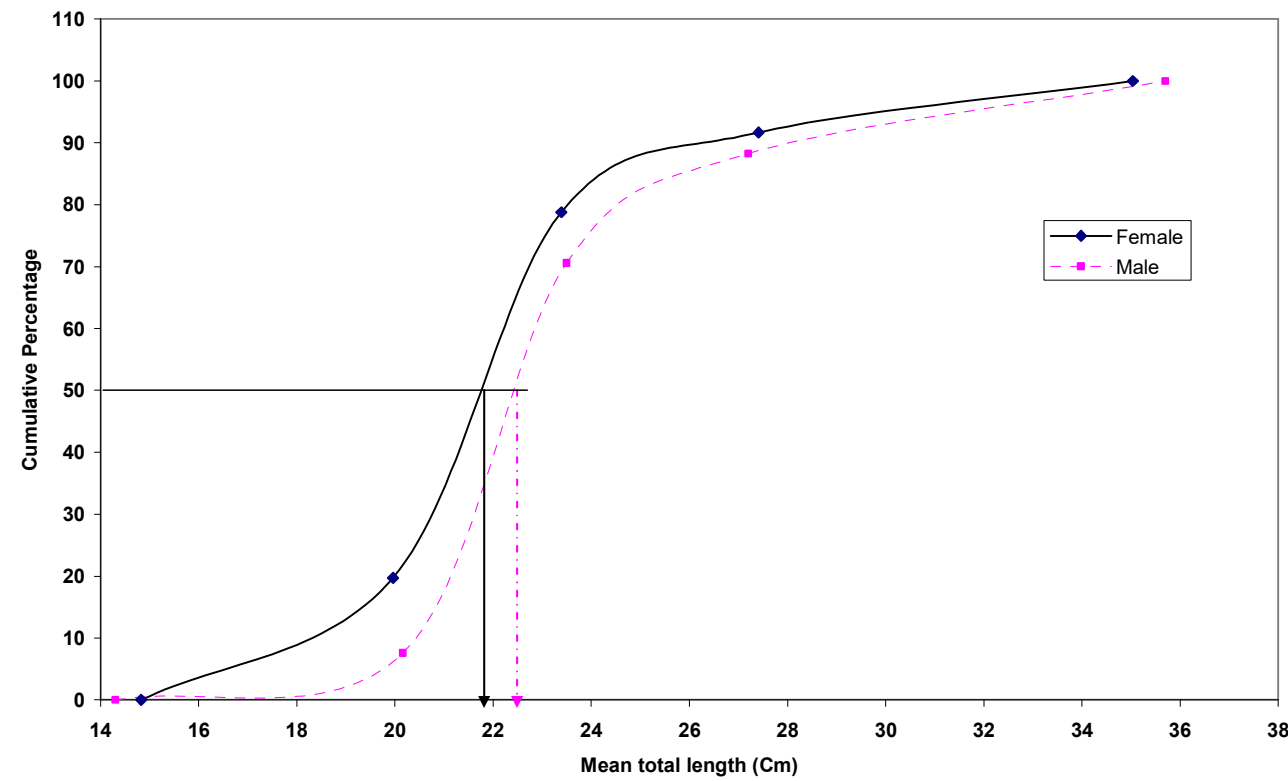

Fig. 3: Shows the percentage of mature males and females for Lethrinus harak with total length, arrows show Length at first sexual maturity.

\section{Histological aspect of gonads development:}

The histological aspect of ovary development and microscopic characteristics were summarized in (Plates 1-17), and (Plates 18-28) of females and males respectively.

The histological aspect of testes development and microscopic characteristics was summarized in (Plates 18-28), of males for Lethrinus harak.

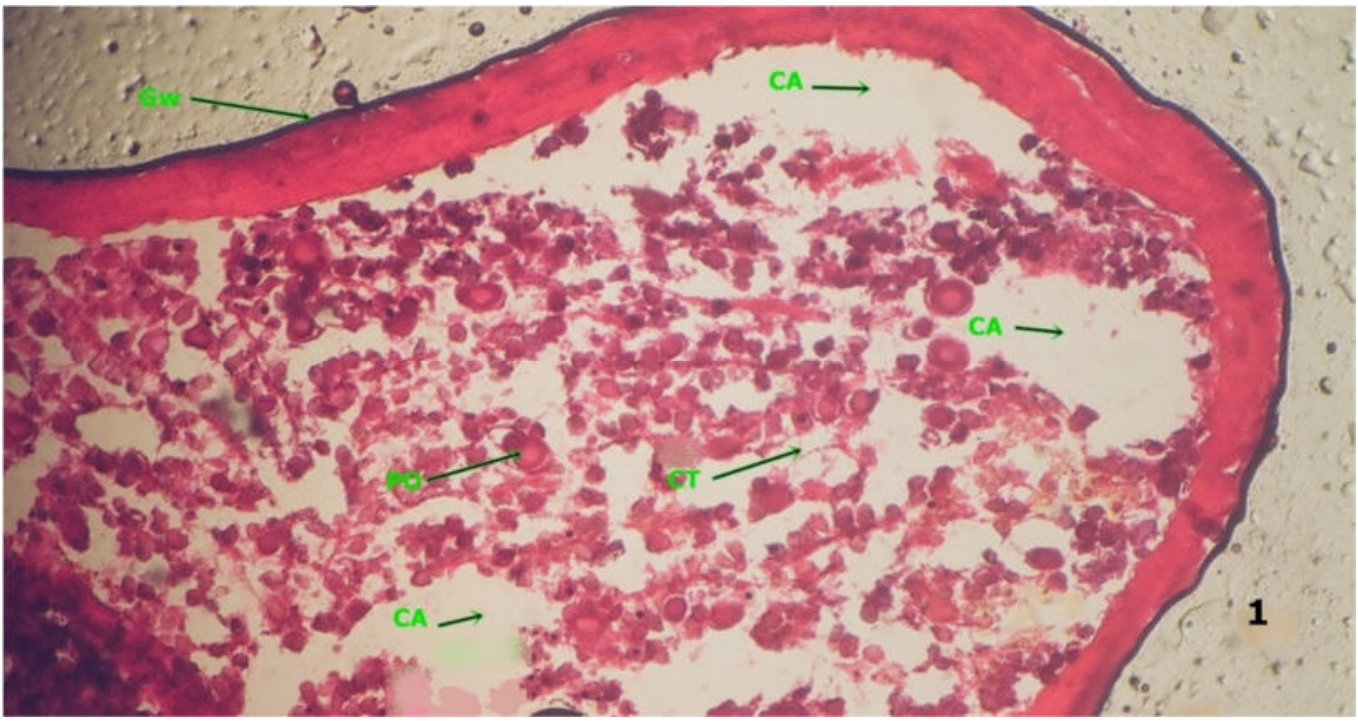

Plate 1 (Whole section, $x=4)$ 


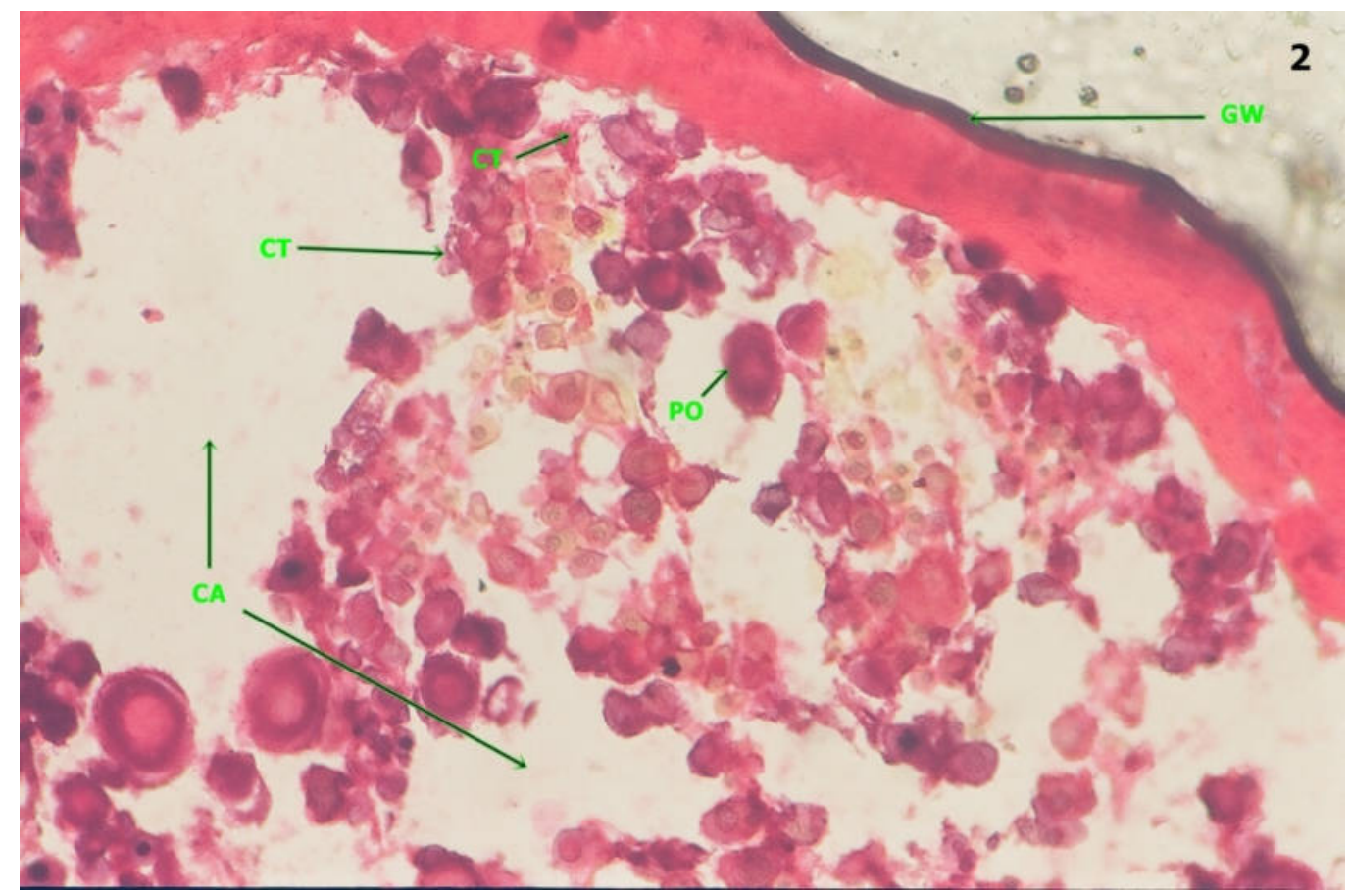

\section{Plate 2 (Enlarged section, $x=10$ )}

Plate (1)and (2) transverse section through the immature ovary (undifferentiated) dominated will afew primary oocytes $(\mathrm{Po})$ around the central cavity(CA) of the connective tissue(CT) in this stage the gonad wall $(\mathrm{GW})$ is very thick, (stained with Hematoxyline and Eosin).

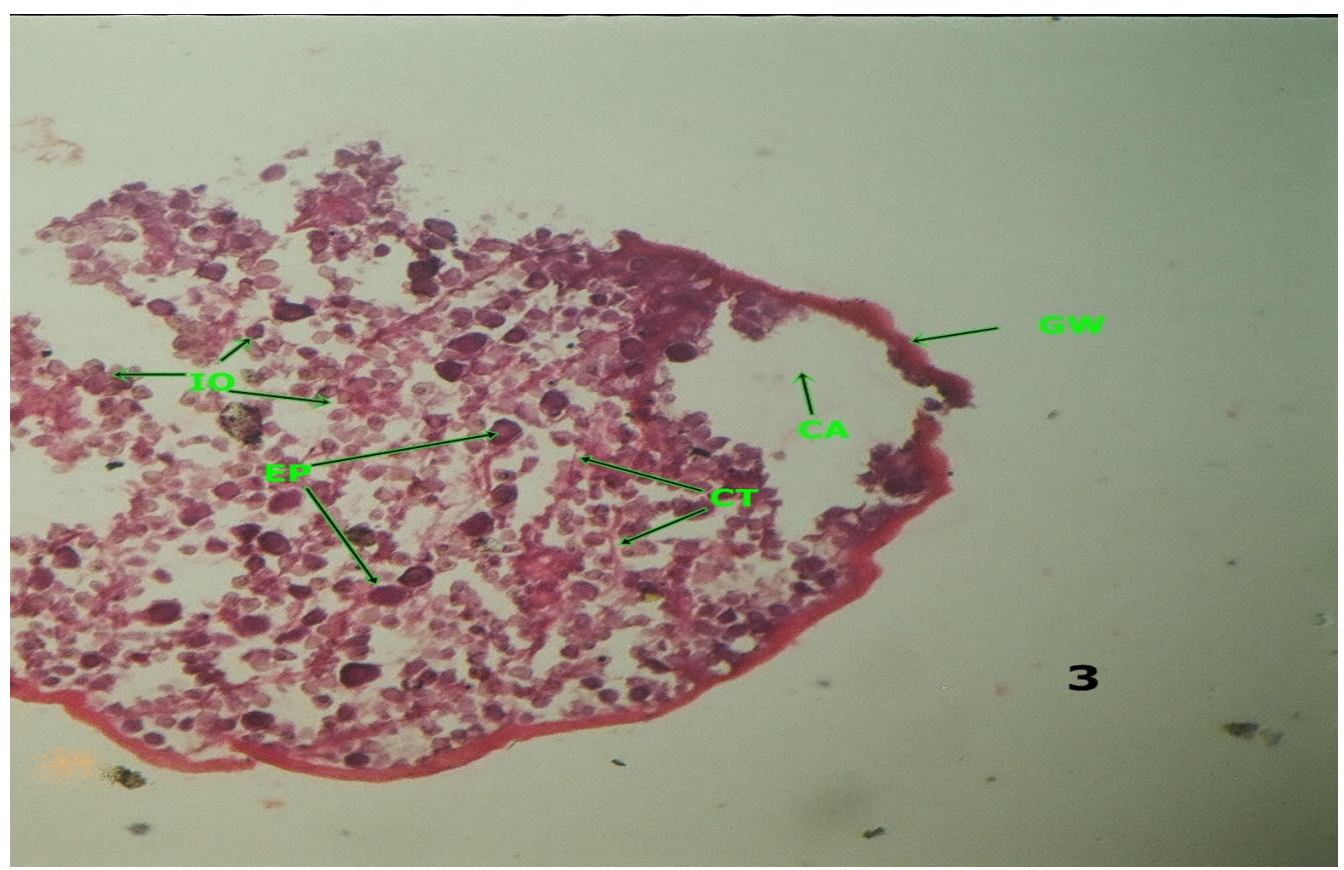

Plate 3 (Whole section, $x=4$ ) 


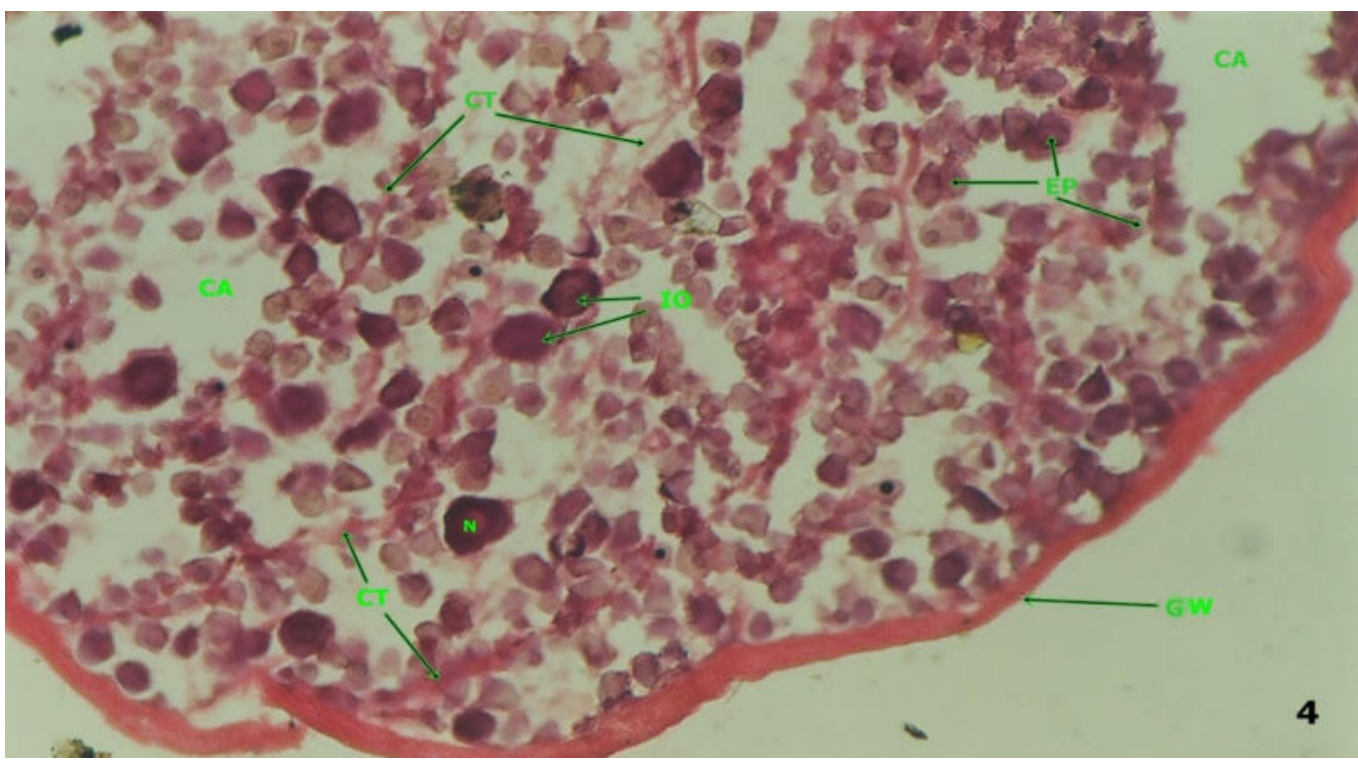

Plate 4 (Enlarged section, $x=10)$

Plate (3) and (4) transverse section through the immature ovary showing gonad wall (GW) is very thick, and a nest of immature oocytes (IO) or oogonia and early perinucleolus (EP). Immature oocytes in this stages were small spherical cells present either solitary or in a cluster of the cells founded embedded in the ovigerous lamella, and the ovarian cavity (CA) is much reduced around the connective tissue, (stained with Hematoxyline and Eosin).

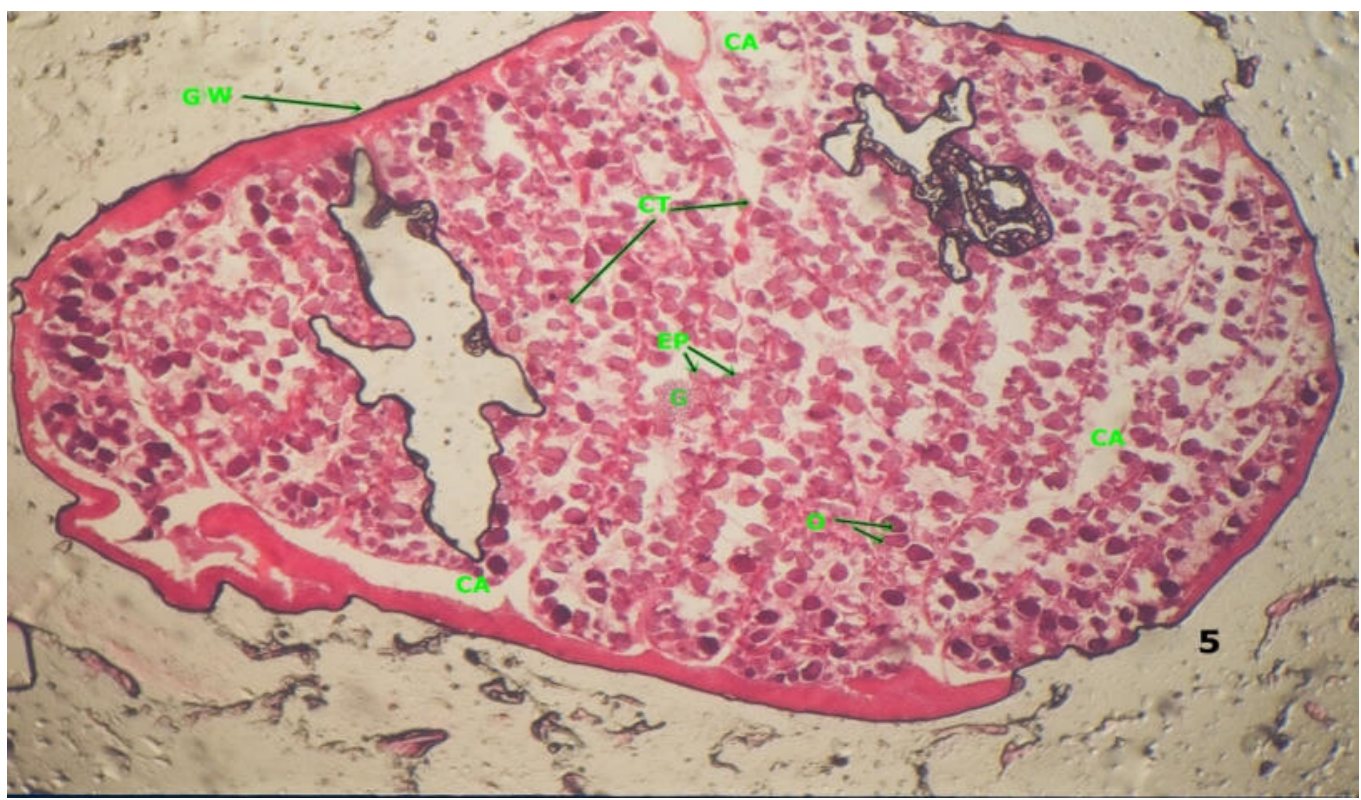

Plate 5 (whole section) 


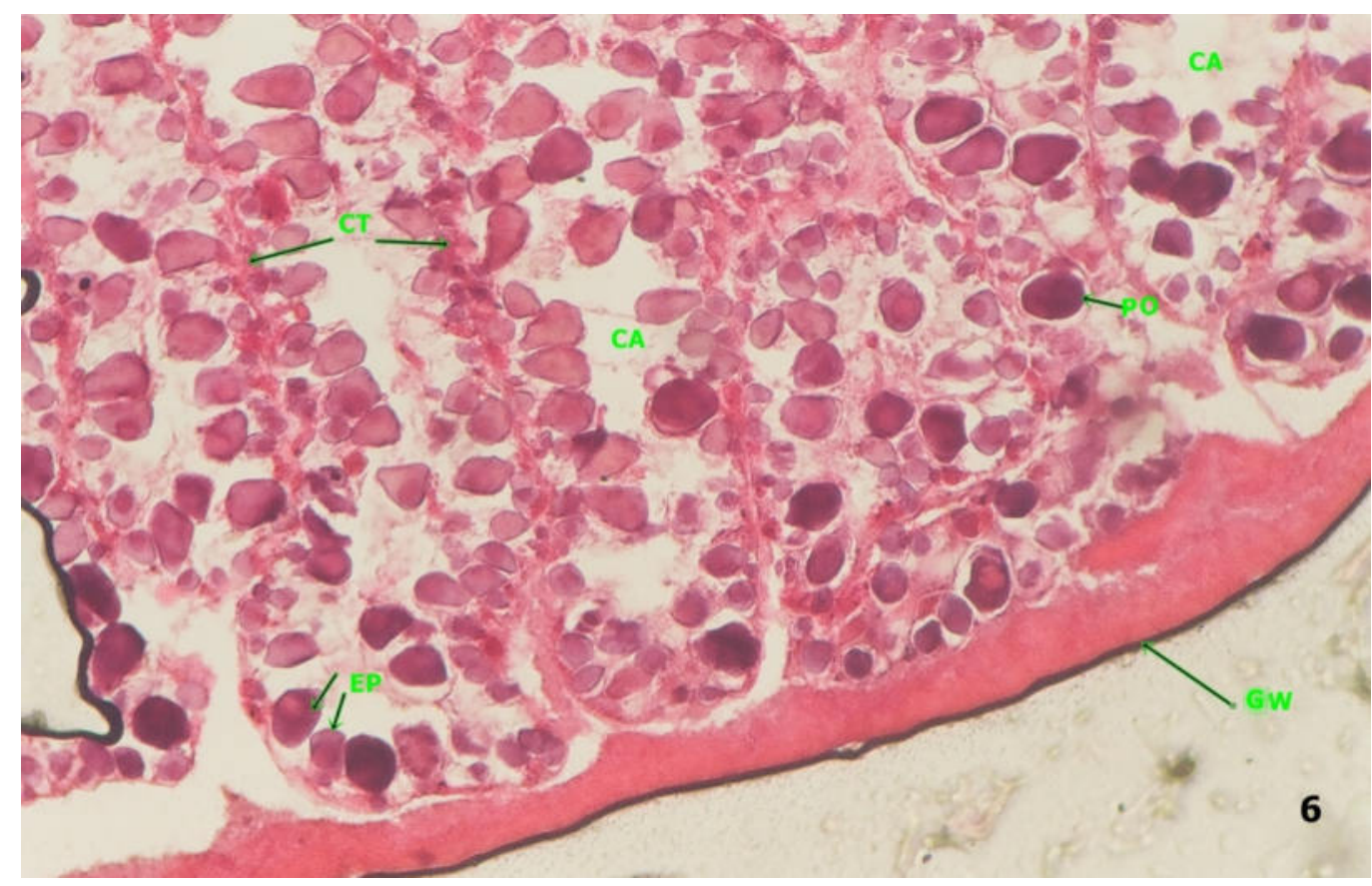

Plate 6 (Enlarged section)

Plate Fig (5) and (6) transverse section through immature ovary were 'containing nest of chromatin nucleolus, oogonia (O) (primary oocytes)

(po) or immature oocytesw (IO); Early perinucleolus(EP) around the cavity(CA) and connective tissue (CT). Showed that oocytes appear small in size and nucleus disappearing or very small. The ovarian cavity is much reduced, (stained with Hematoxyline and Eosin).

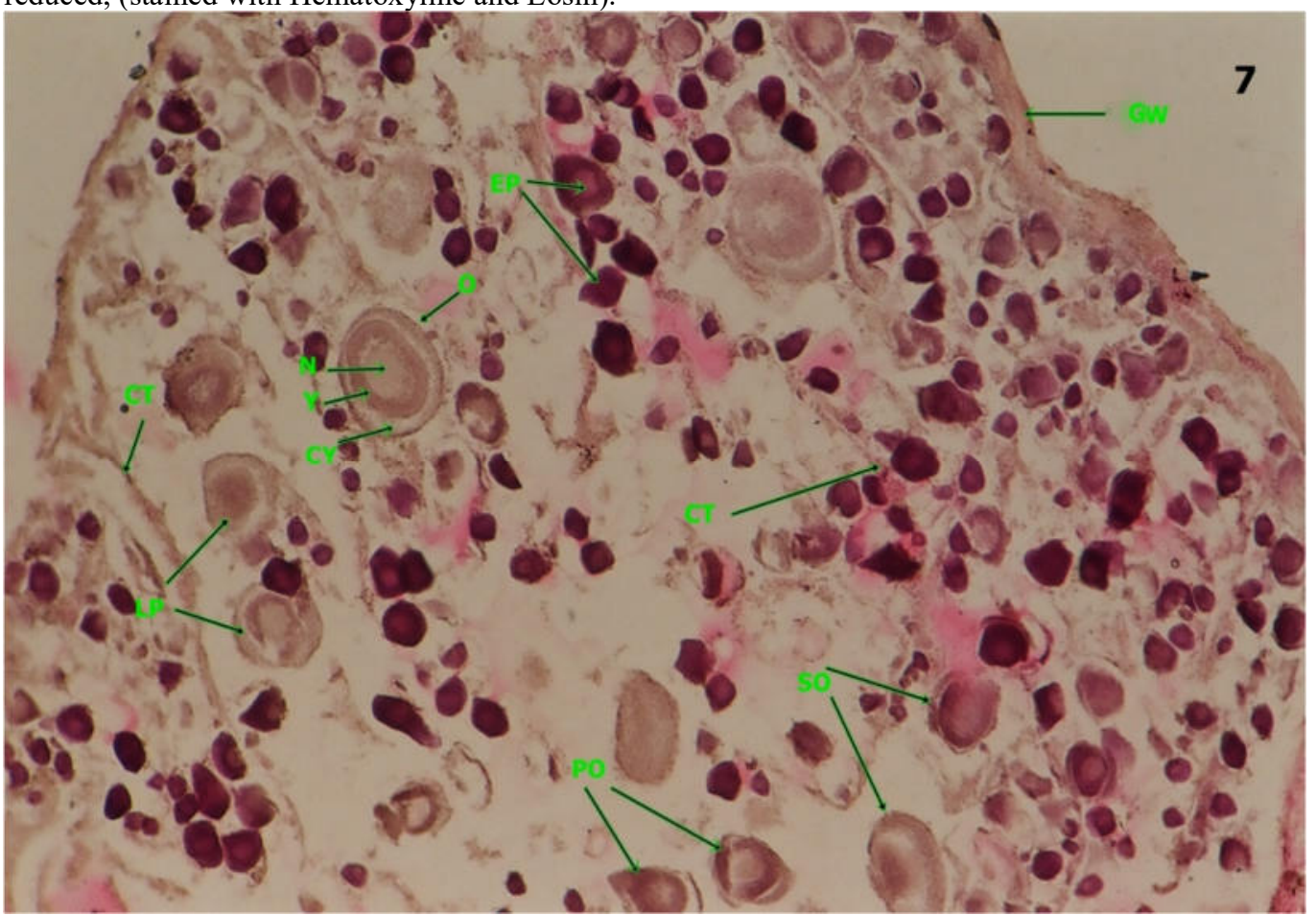

Plate 7 (Whole section, $x=10)$

Plate (7) transverse section through the developing ovary from immature to maturing there have much connective tissue (CT) between follicles, gonad wall $(\mathrm{GW})$ still is thick. Large circular nucleus $(\mathrm{N})$ is seen with a number of small nucleoli $(\mathrm{Nu})$. In this stage, the young oocytes increase in size, early perinucleolus; extensive cytoplasm(CY) 
the late perinuleolus $(\mathrm{LP})$ spherical in shape, the oocytes $(\mathrm{O})$ have yolk $(\mathrm{Y})$.Many oocytes are observed, egg follicles started to appear in number, (stained with Hematoxyline and Eosin).

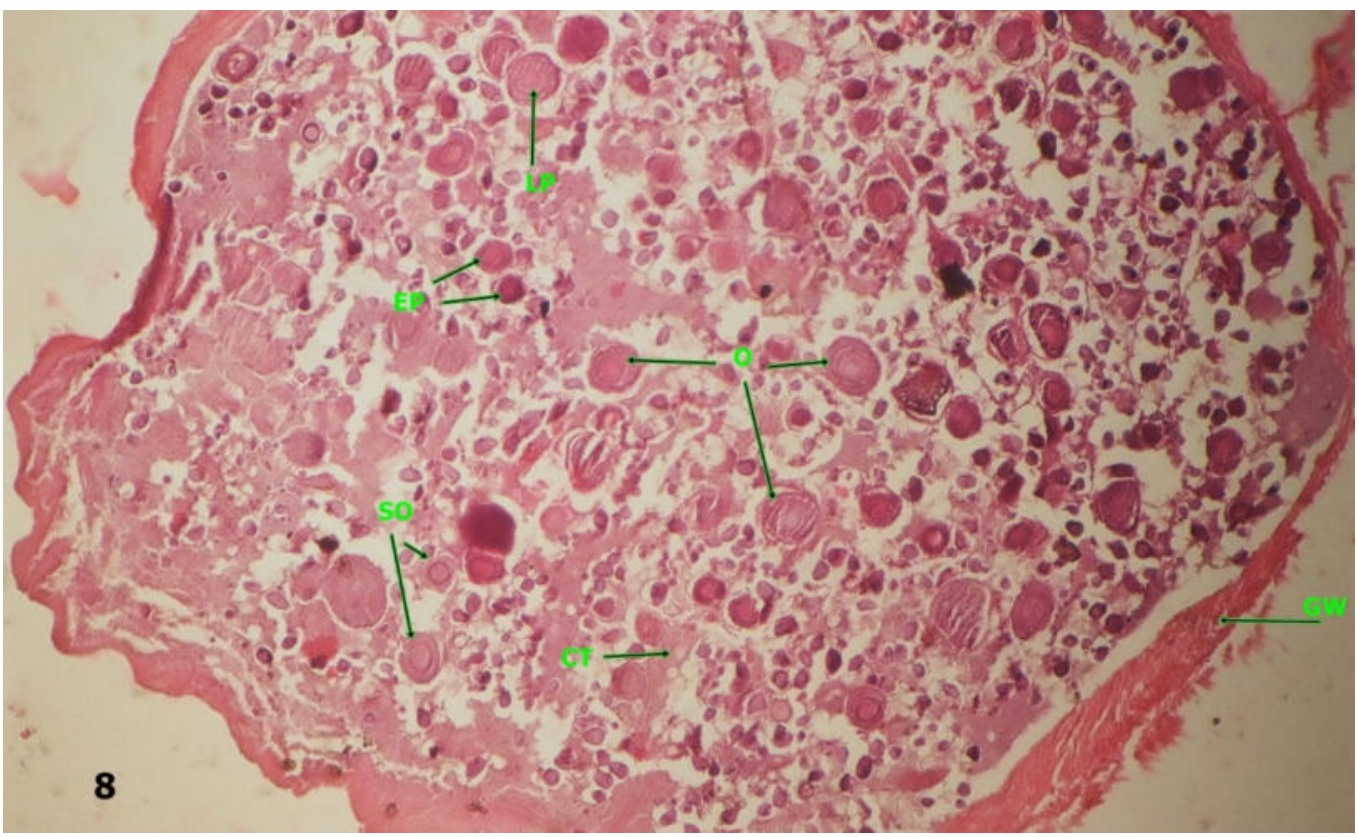

Plate 8 (Whole section, $x=4)$

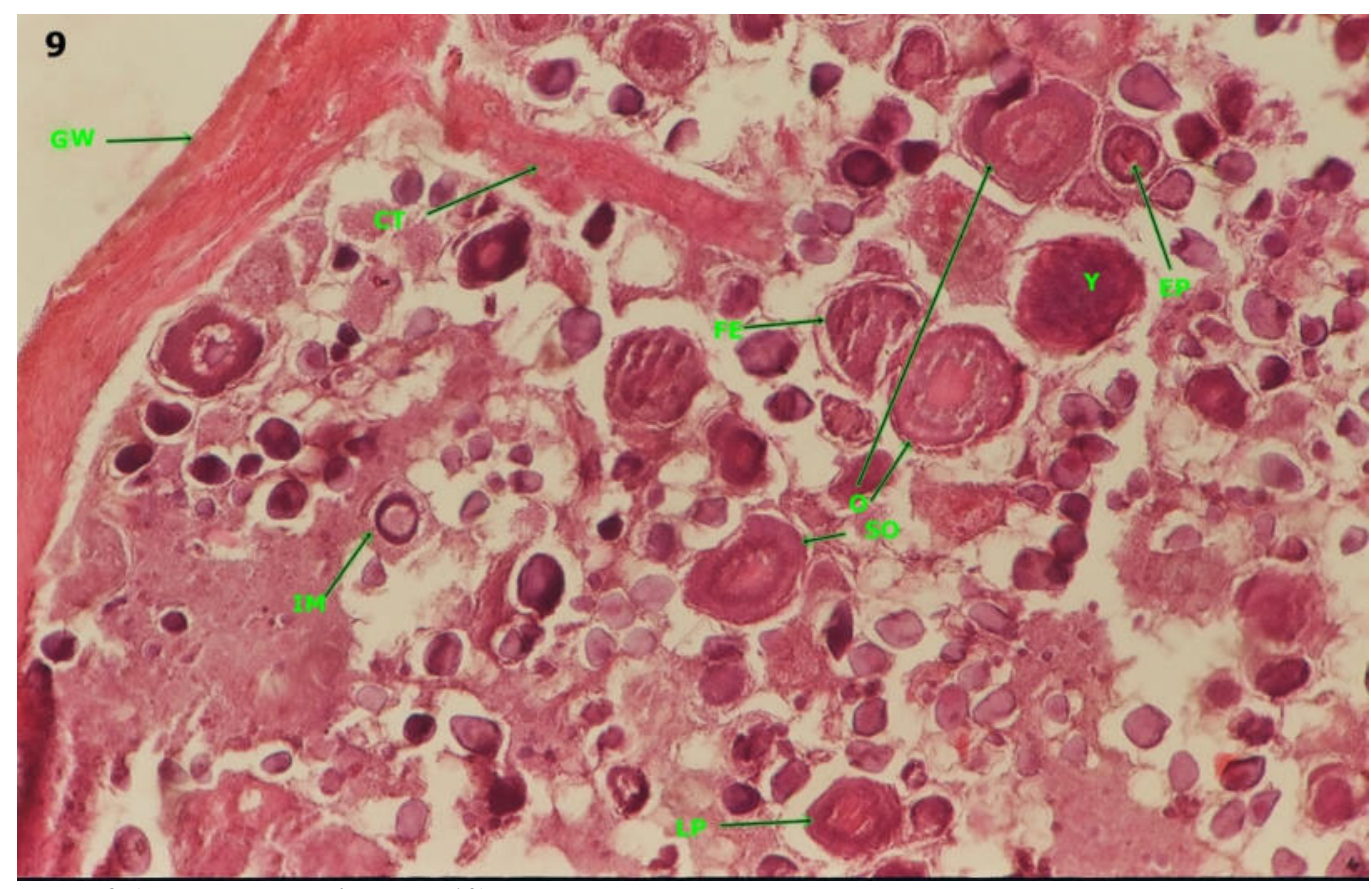

Plate 9 (Enlarged section, $x=10)$

Plate (8) and (9) transverse section through the maturing ovary the gonad wall (GW)is thick, as the growth of the oocytes $(\mathrm{O})$ progress they increase in size, and surrounded with follicular epithelial (FE). In this stage having early perinucleolus (EP), late perinucleolus, and secondary oocytes (SO), (stained with Hematoxyline and Eosin). 


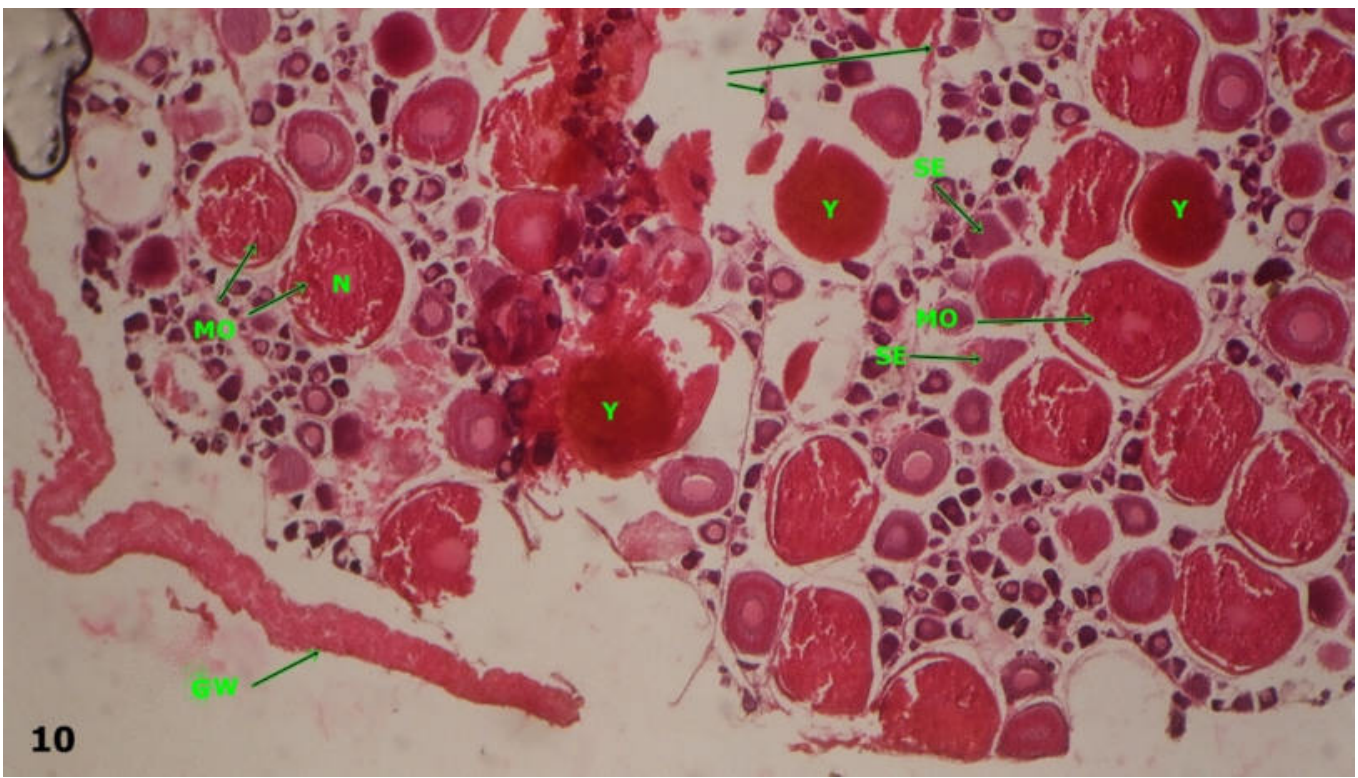

Plate 10 (Whole section, $x=4)$

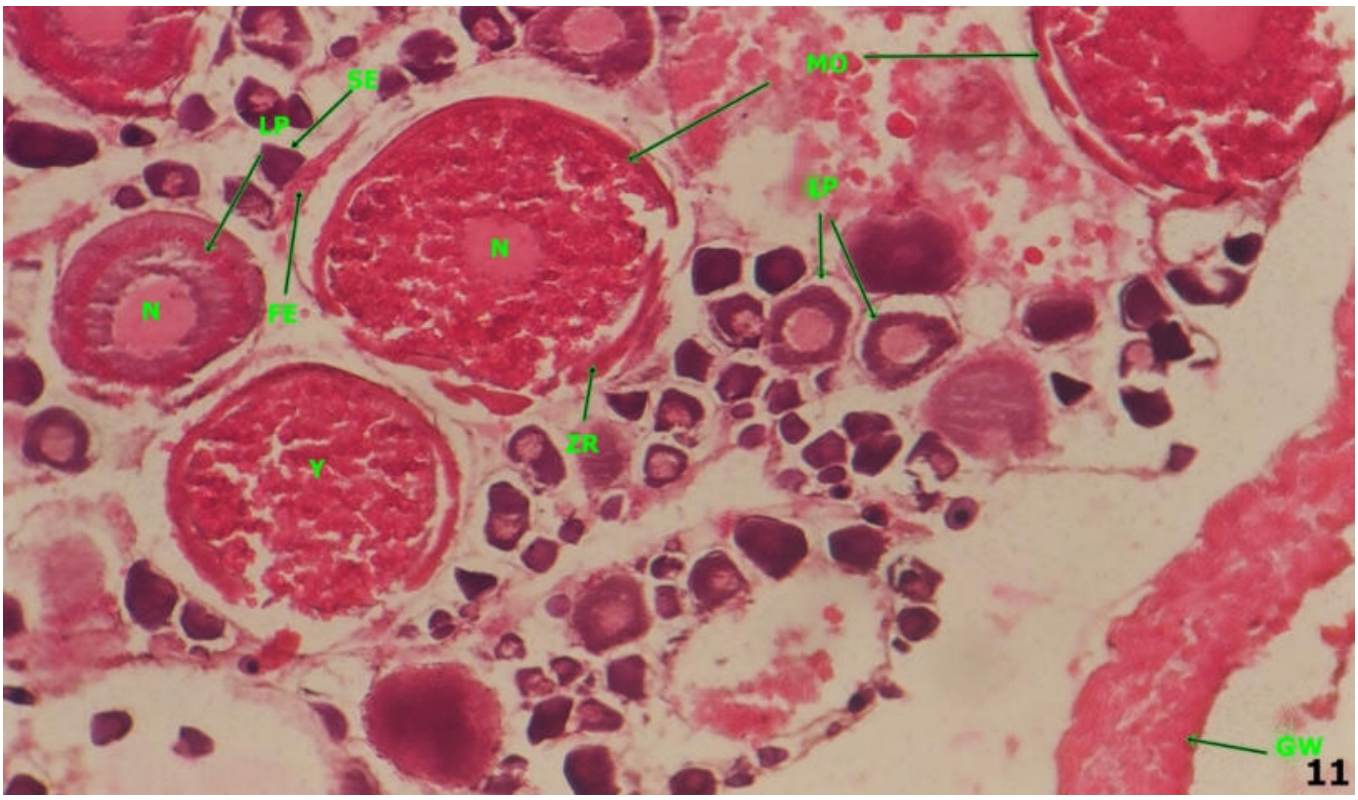

Plate 11 (Enlarged section, $x=10)$

Plate (10) and (11) transverse section through the second stage maturing ovary showing the beginning atresia hypertrophic folliculars cells and material yolk(Y) and zona radiate (ZR). Mature oocyte (MO) with a follicular epithelial layer(FE). The cytoplasm is basophilic and occupies the greater part of the ovum the nucleus $(\mathrm{N})$ is round in shape, the nucleoli increase in in number and become smaller size and locate near the periphery of the nucleus, (stained with Hematoxyline and Eosin). 


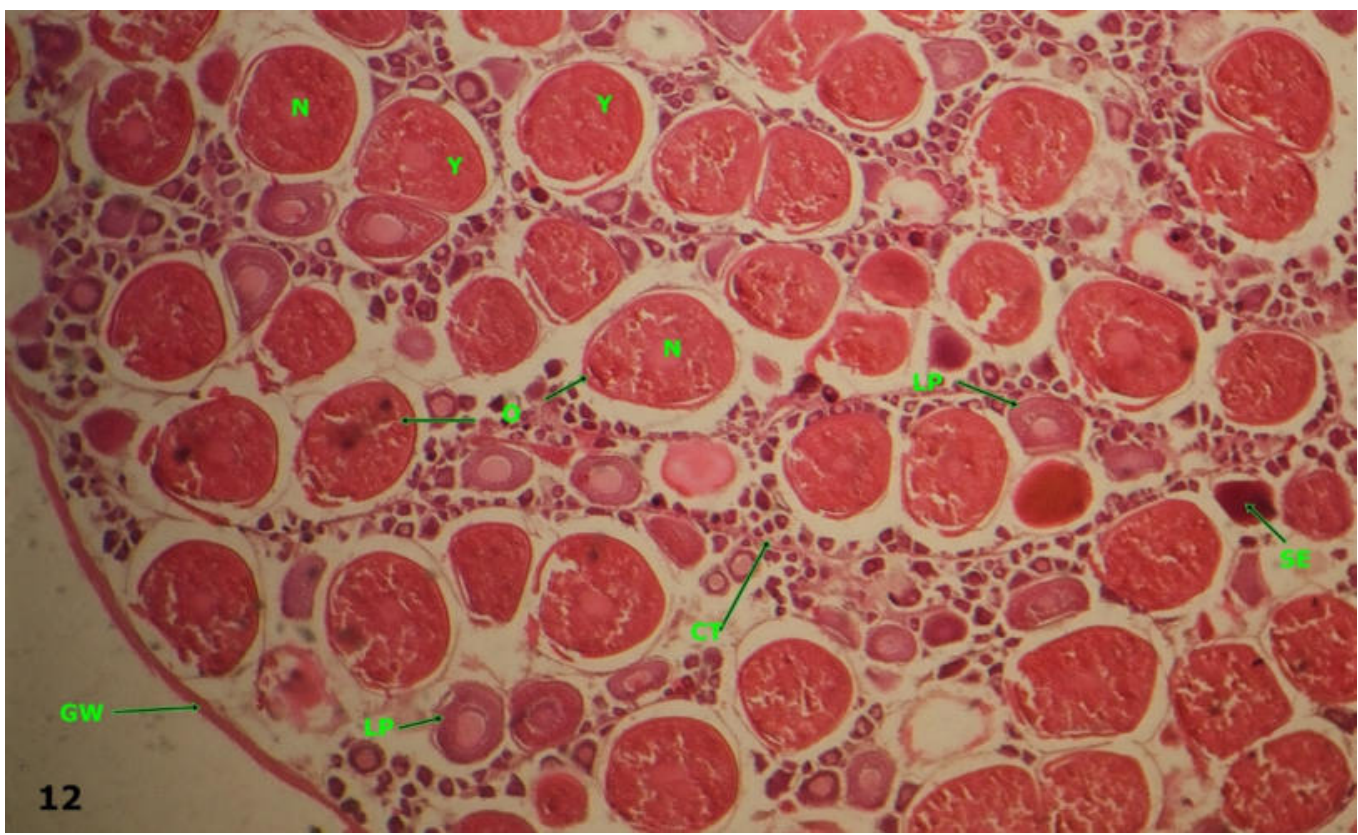

Plate 12 (Whole section, $x=4)$

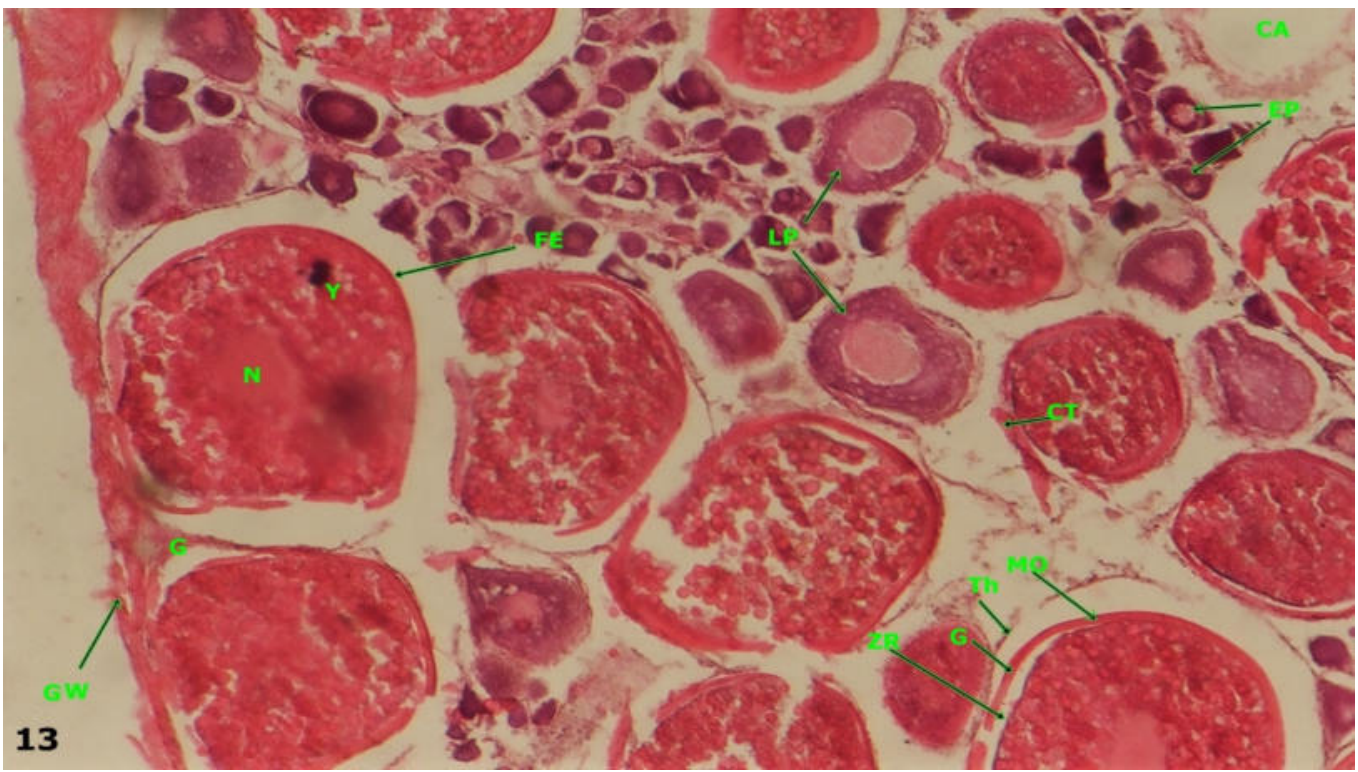

Plate 13 (Enlarged section, $x=10)$

Plate (12) and (13) transvere section through maturing ovary (near mature) the ovary is filled with oocytes $(\mathrm{O})$ different stage of yolk $(\mathrm{Y})$ deposition, nucleus $(\mathrm{N})$ in central position, the mature oocytes $(\mathrm{MO})$ have thecal cells $(\mathrm{Th})$, granulosa $(\mathrm{G})$ zona radiata $(\mathrm{ZR})$, oocyte bounded by a distinct follicular epithelial(FE).The yolk granules appeared as small spheres in the inner part of cytoplasm around the nucleus, the oocyte membrane in thick ness and composed of three layer outer(Th) middle (G) inner (ZR), (stained with Hematoxyline and Eosin). 


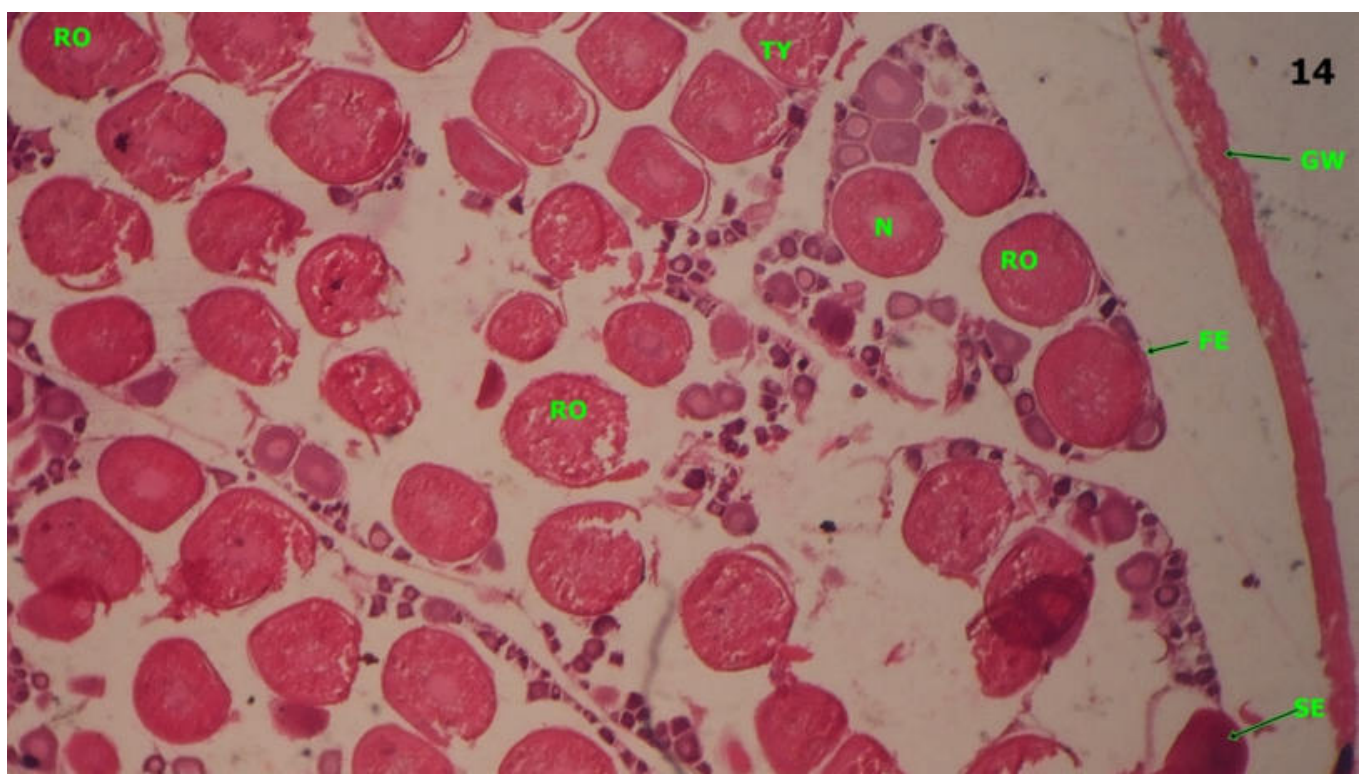

Fig 14 (Whole section, $x=4)$

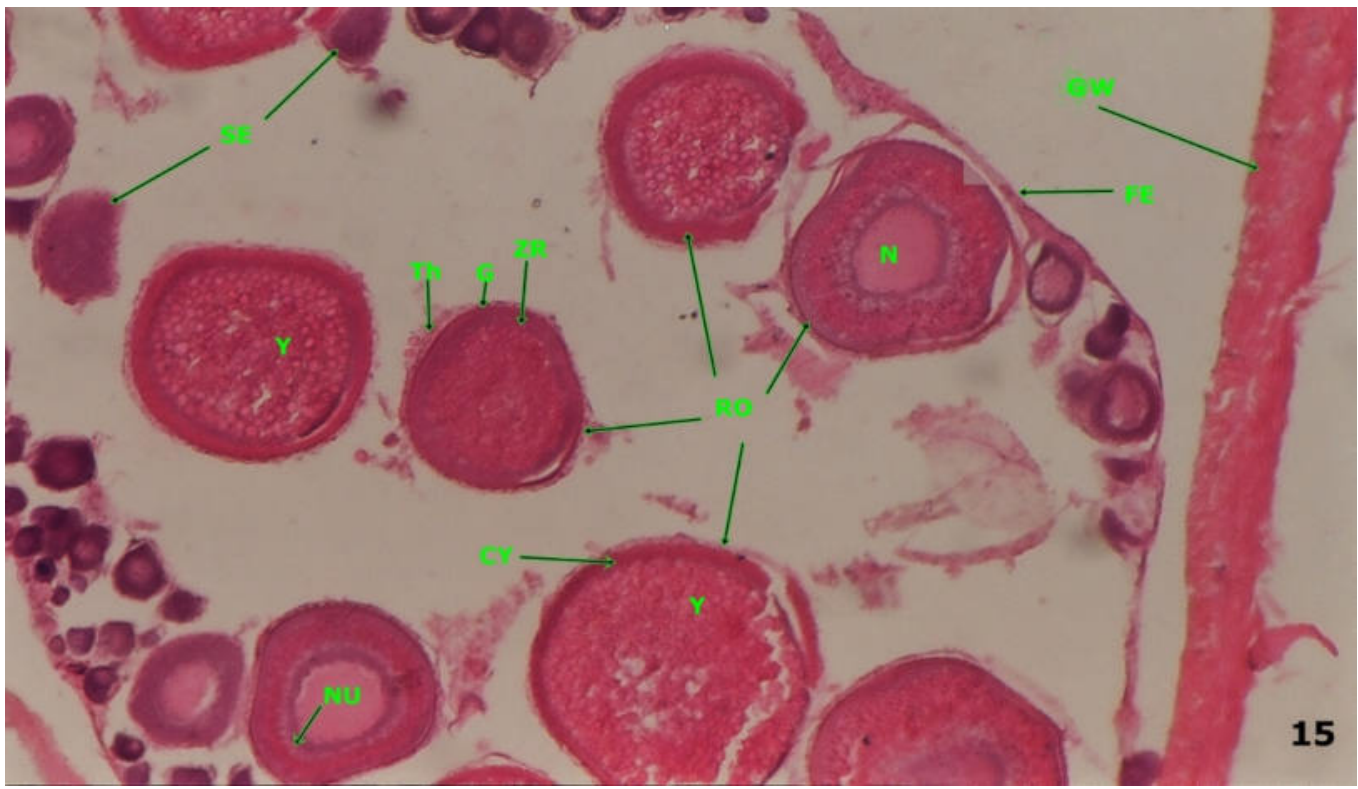

Plate 15 (Enlarged section, $x=10)$

Plate (14) and (15) transverse section through the full mature ovary the ovary is filled with fully ripe oocytes (RO) and having small distinguisted spheres of yolk depositions, oocytes size and become oval in shape, the three layer thecal (Th), granulosa $(\mathrm{G})$, zona radiata (ZR), appeared in clear, and spherical teriary yolk (TY), the ovary composes beside the eggs wich had reached final maturation, few small eggs with different diameters as well as some oocytes in atretic state, (stained with Hematoxyline and Eosin). 


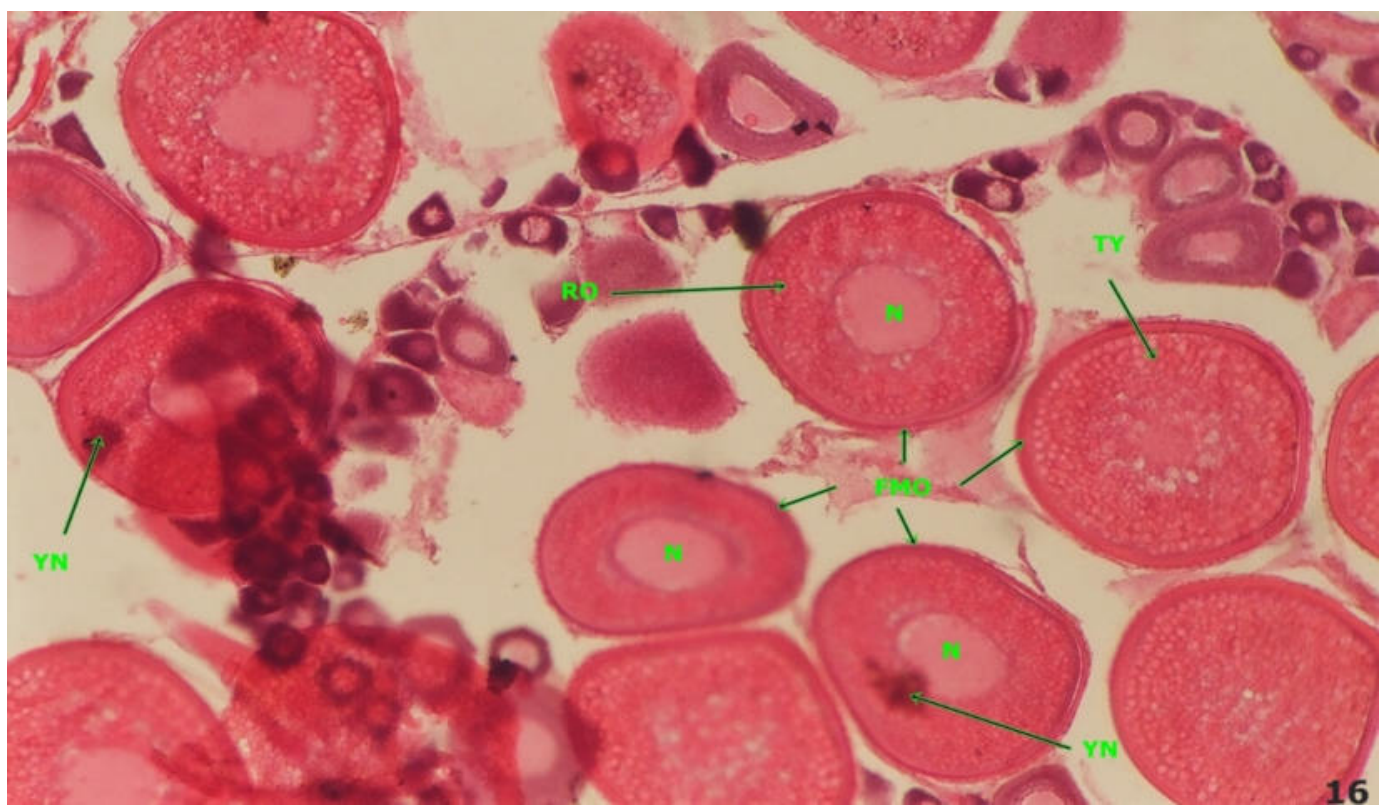

Plate $16($ Whole section, $x=10)$

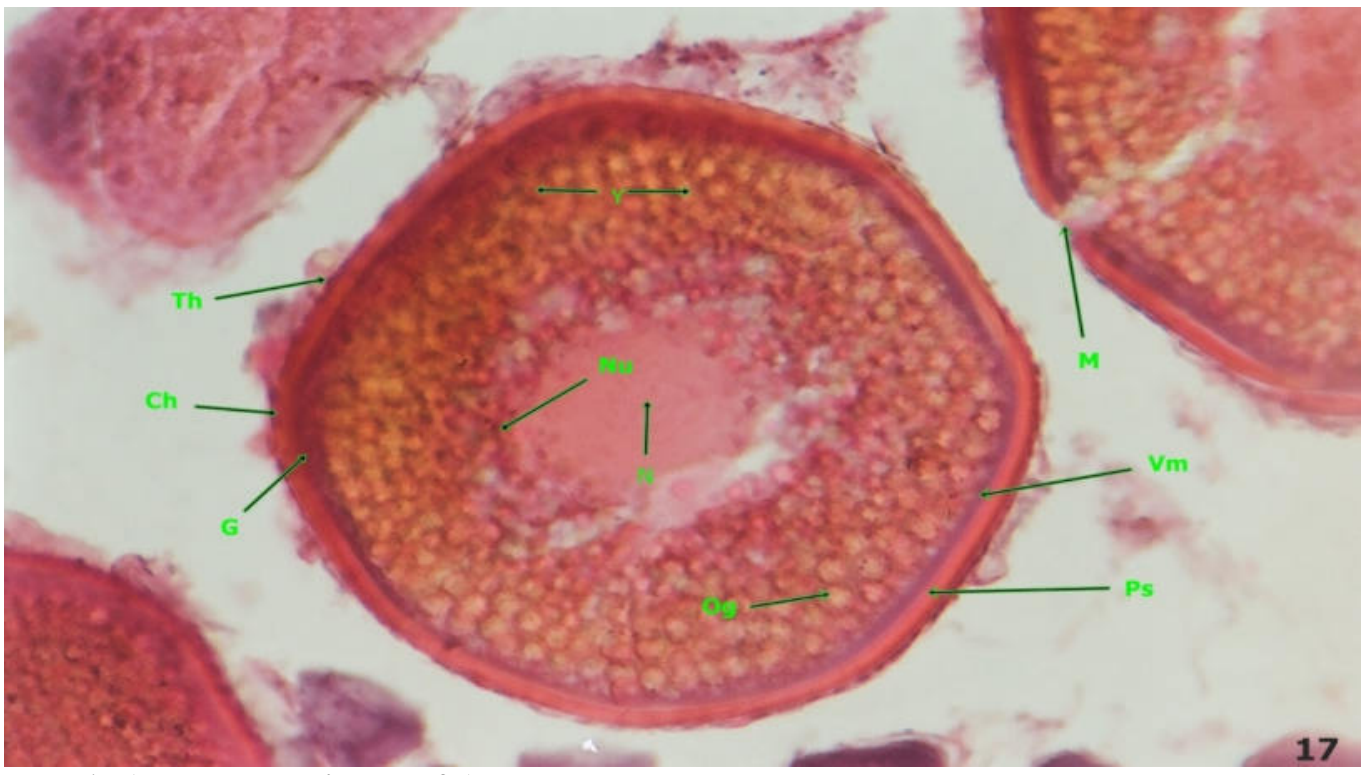

Plate 17 (Enlarged section, $x=25)$

Plate (16) and(17) transverse section of spawning ovary showing spherical tertiary yolk (TY) and oval ripe oocyte (Ro). The ovary full mature oocyte(FMO), the structure of an unfertilized fish egg nucleus (N), micropyle (M), chorion $(\mathrm{Ch})$, yolk $(\mathrm{Y})$, oil globules $(\mathrm{Og})$, vitelline membrance $(\mathrm{Vm})$, perivitelline space $(\mathrm{Ps})$, theca(Th), granulose $(\mathrm{G})$, cytoplasm $(\mathrm{Cy})$, yolk nucleus(YN).the granulosa cells are hypertrophied, and thecal cells transform into macrophages to invade the oocyte contents, The spawning ovary were observed most months of the year but peak in other from October to April for L. harak (stained with Hematoxyline and Eosin). 


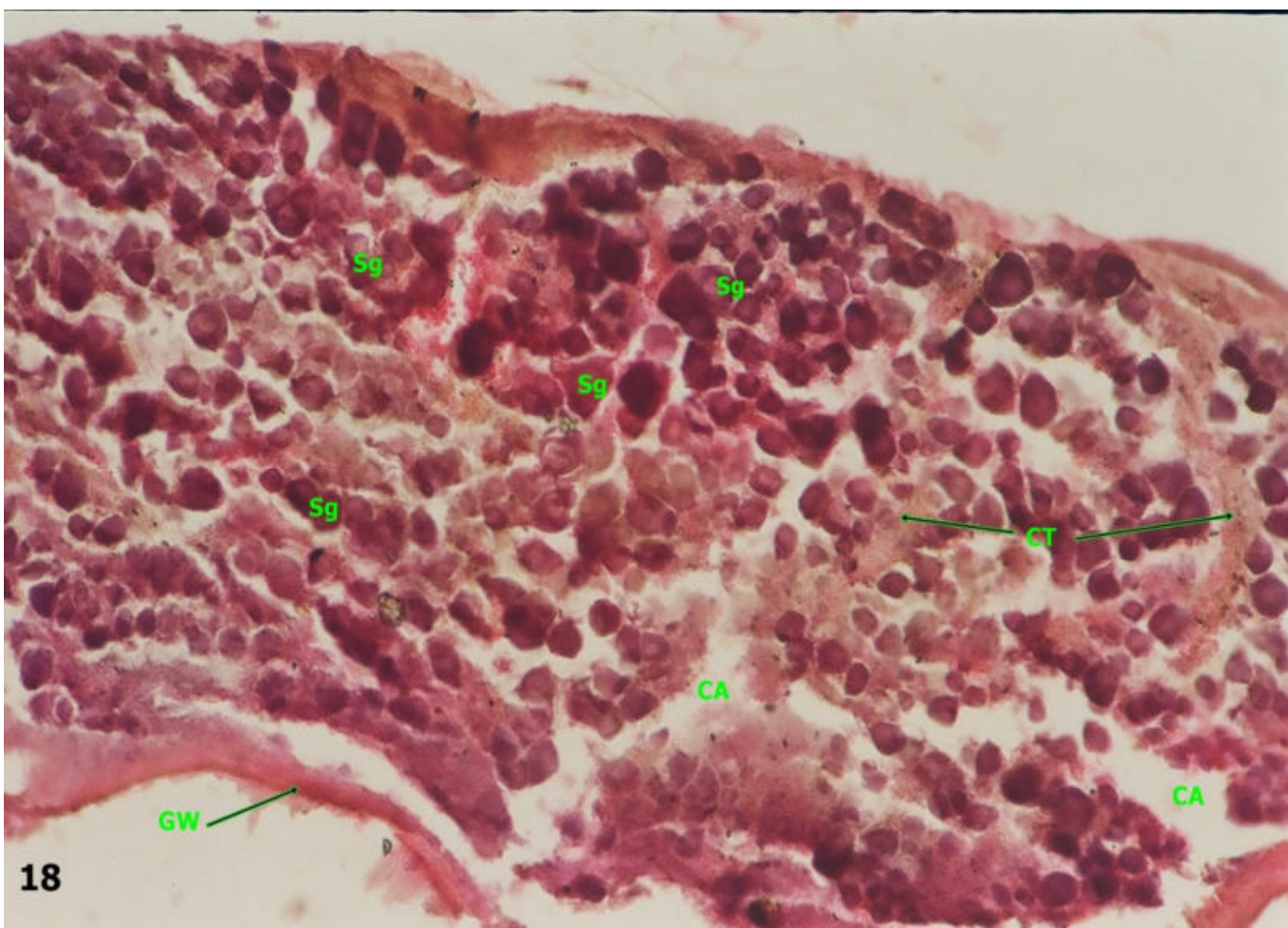

Plate 18 (Whole section, $x=10$ )

Plate (18) transverse section through the immature testes, showing a preponderance of spermatogonia (Sg), there are the primary germ cells. They undergo repeated mitotic divisions to form a large number of spermatogonia. It the first spermatogonial stage in the testes. The gonad wall (GW) is thick, and inter lobular connective tissue (CT), and cavity (CA). The seminiferous lobules at immature stage composed of the germ cells which are in active. They designate spermatogonium at a different stage, (stained with Hematoxyline and Eosin).

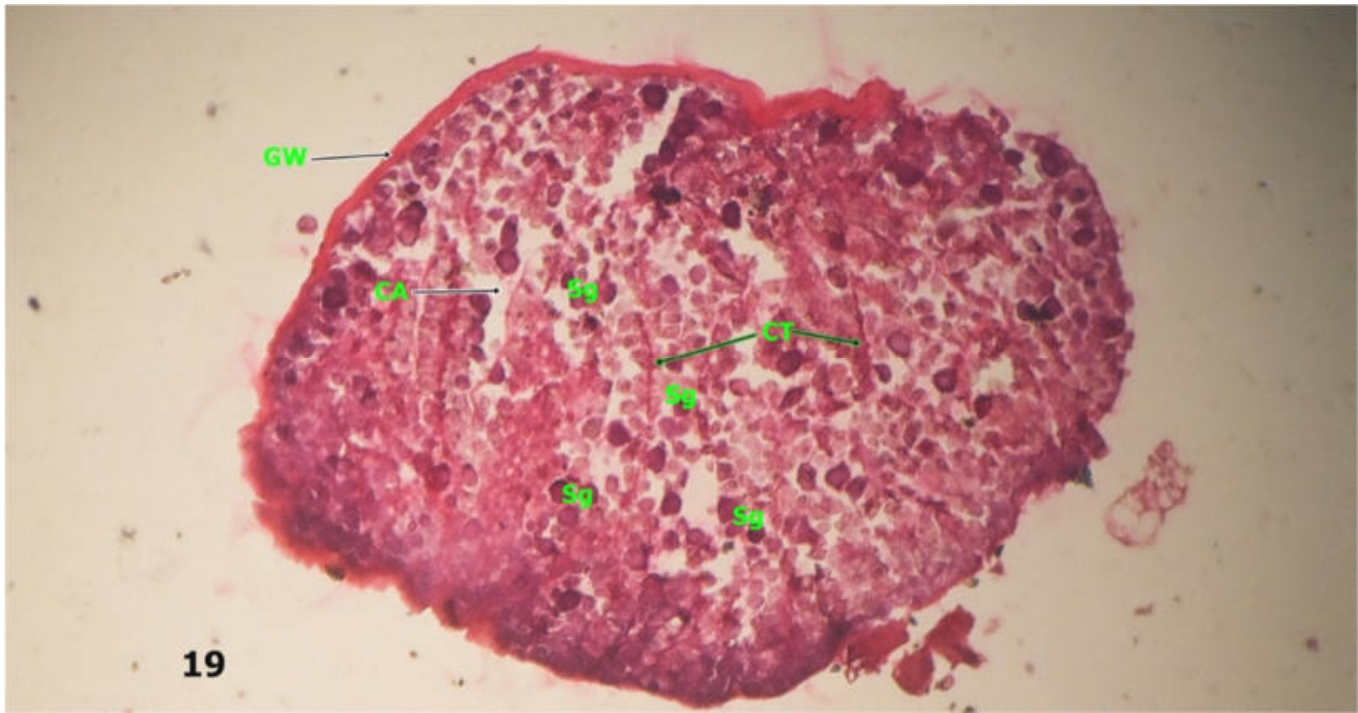

Plate 19(Whole section, $x=4)$ 


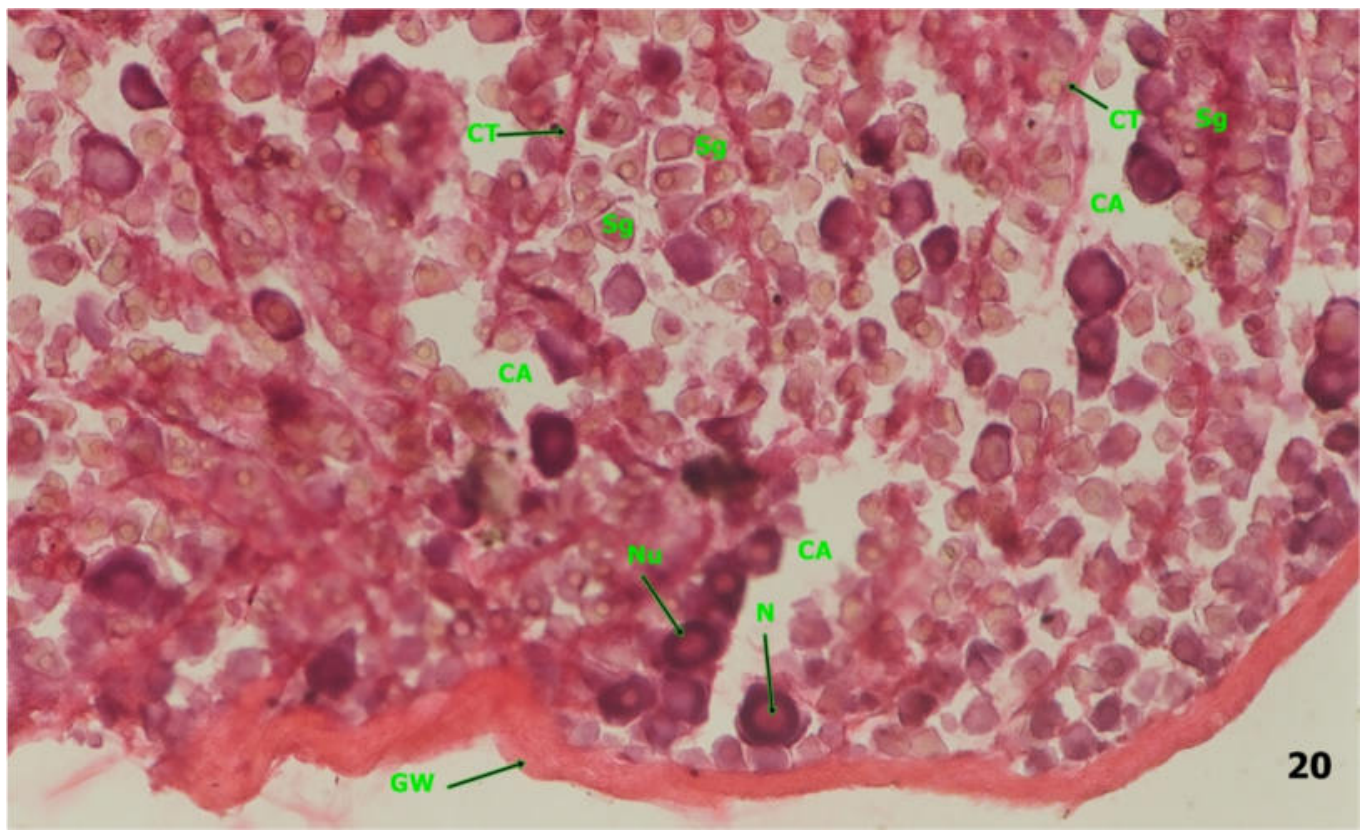

Plate 20(Enlarged section, $x=10)$

Plate (19) and(20) transverse section through immature testes contained fibrous connective tissue (CT), thick gonad wall $(\mathrm{GW})$, the cavity (CA), and spermatogonia(sg). In this stage, the formed spermatogonium is nearly round the nucleus $(\mathrm{N})$ of which have a much greater there is one nucleolus that lies in the center of some cells but others located in the periphery of the nucleus (stained with Hematoxyline and Eosin).

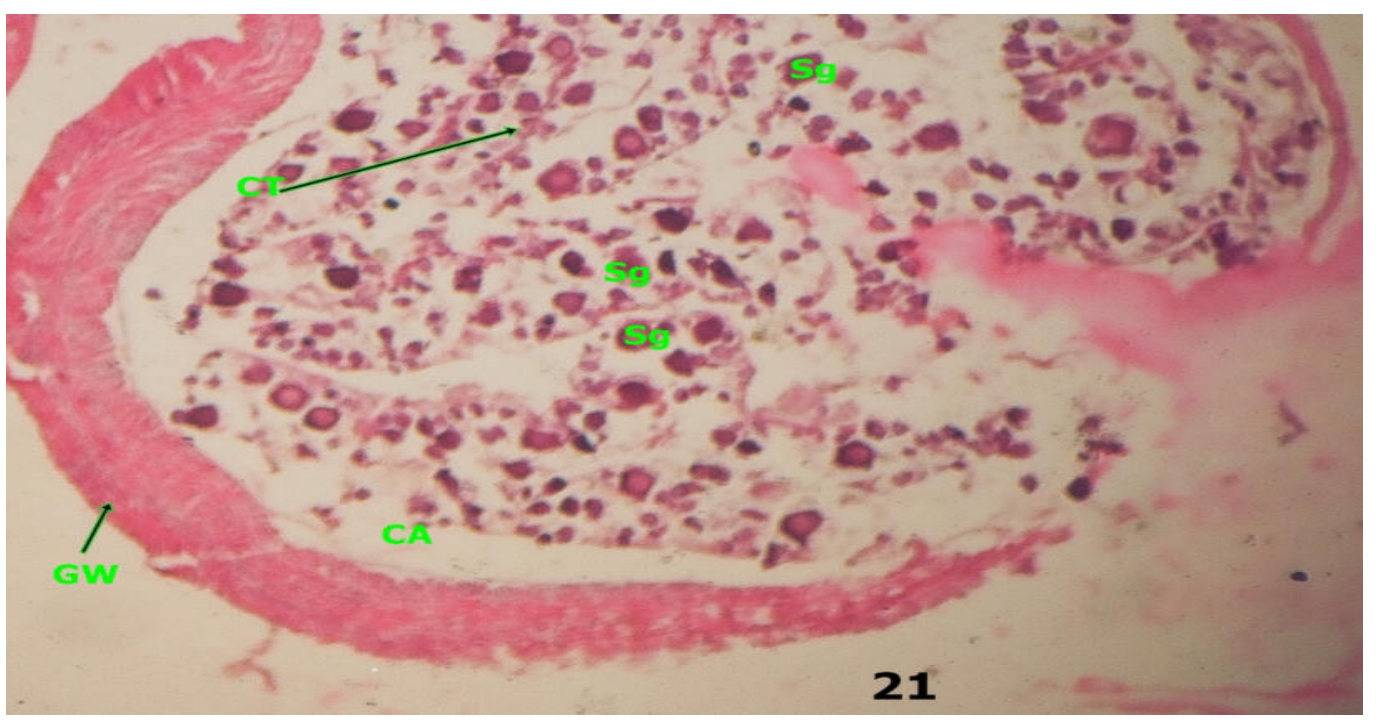

Plate 21 (Whole section, $x=4$ ) 


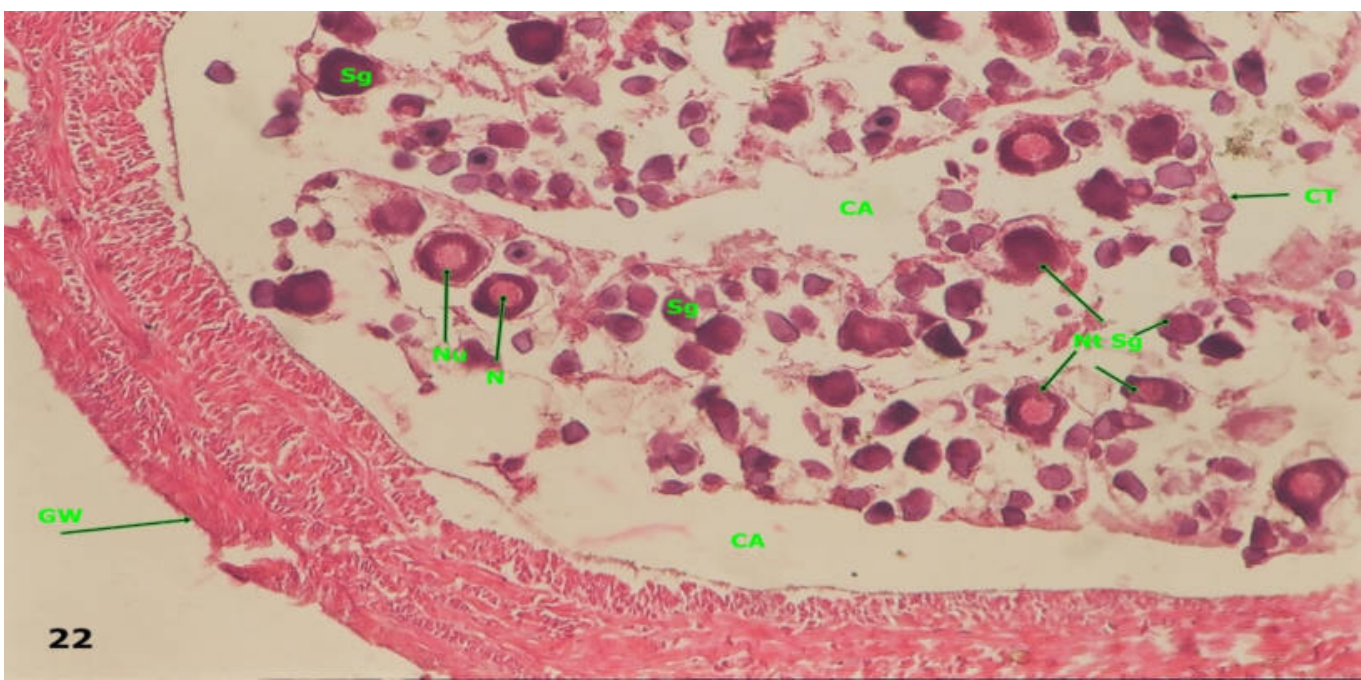

Plate 22 (Enlarged section, $x=10$ )

Plate (21)and(22) transverse section through the immature testes were containing nest of spermatogonia (Nt $\mathrm{Sg})$, and the gonad wall (GW) still very thick, many cavity (CA) and connective tissue (CT), visible among spermatogonia $(\mathrm{Sg})$ in lobules, nucleus $(\mathrm{N})$ nucleolus $(\mathrm{Nu})$. The chromatin material is arranged in the peripheral part of the nuclear membrane, the cytoplasm appeared lightly eosinophilic while the nucleoplasm was slightly basophilic.

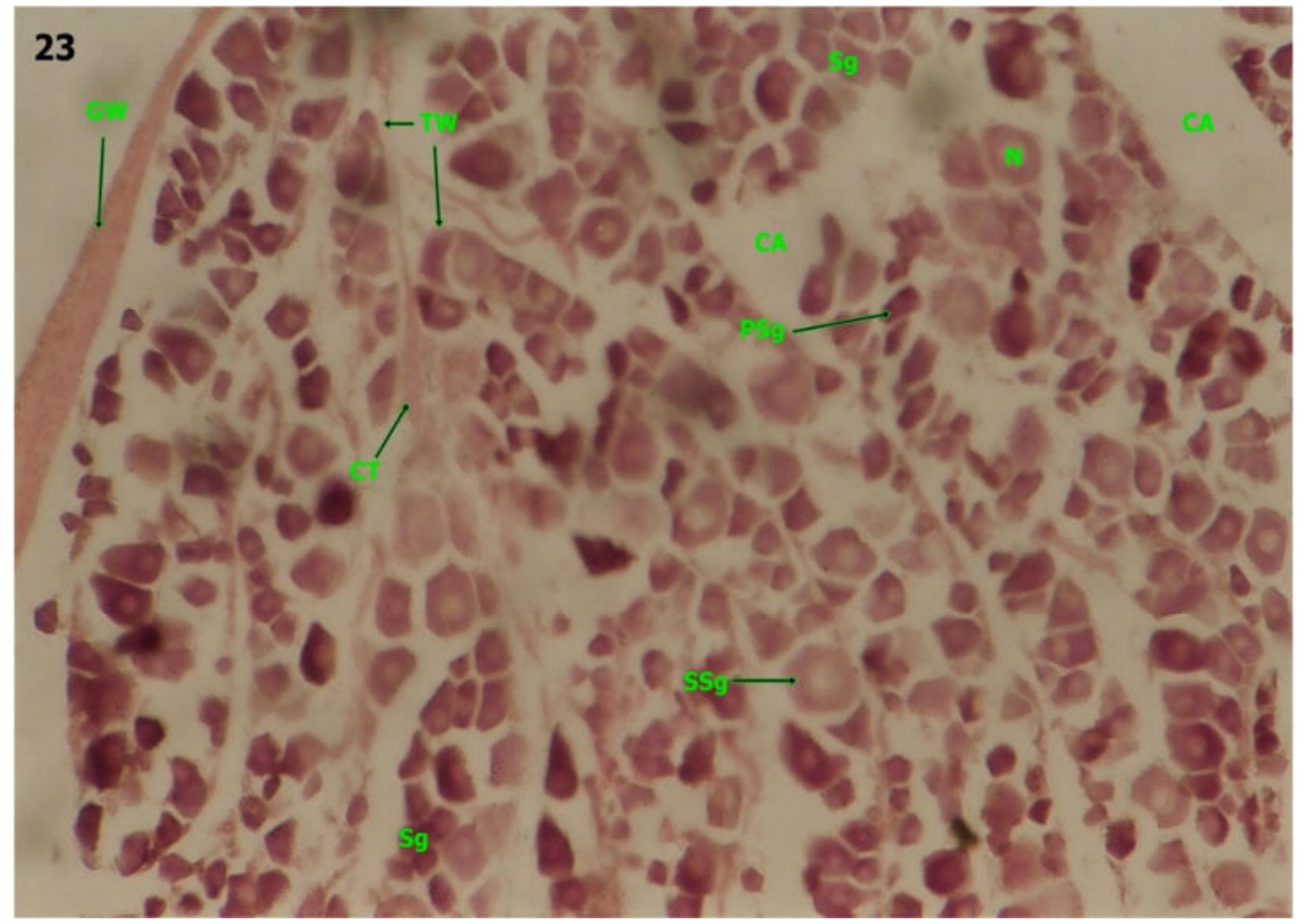

Plate 23 (Whole section, $x=10)$

Plate (23) transverse section through the developing teses showing spermatogonia ( $\mathrm{Sg}$ ) with multiplying another type of spermatocytes is primary spermatocytes (PSg) secondary spermatocytes ( $\mathrm{SSg}$ ), in this stage the gonad wall (GW) become thin and many cavity (CA) among connective tissue (CT) and tubule wall (TW) appears. As spermatogenesis proceeded, spermatogonia divided and multiplied to give the primary spermatocytes, the lobule exhibited the presence of spermatogonia and primary spermatocytes, the latter appeared smaller than 
spermatogonia, the cell out-line are not well defined the nucleus is spherical and measured this stage is characterized by condensed chromatin material of their nuclei (stained with Hematoxyline and Eosin).

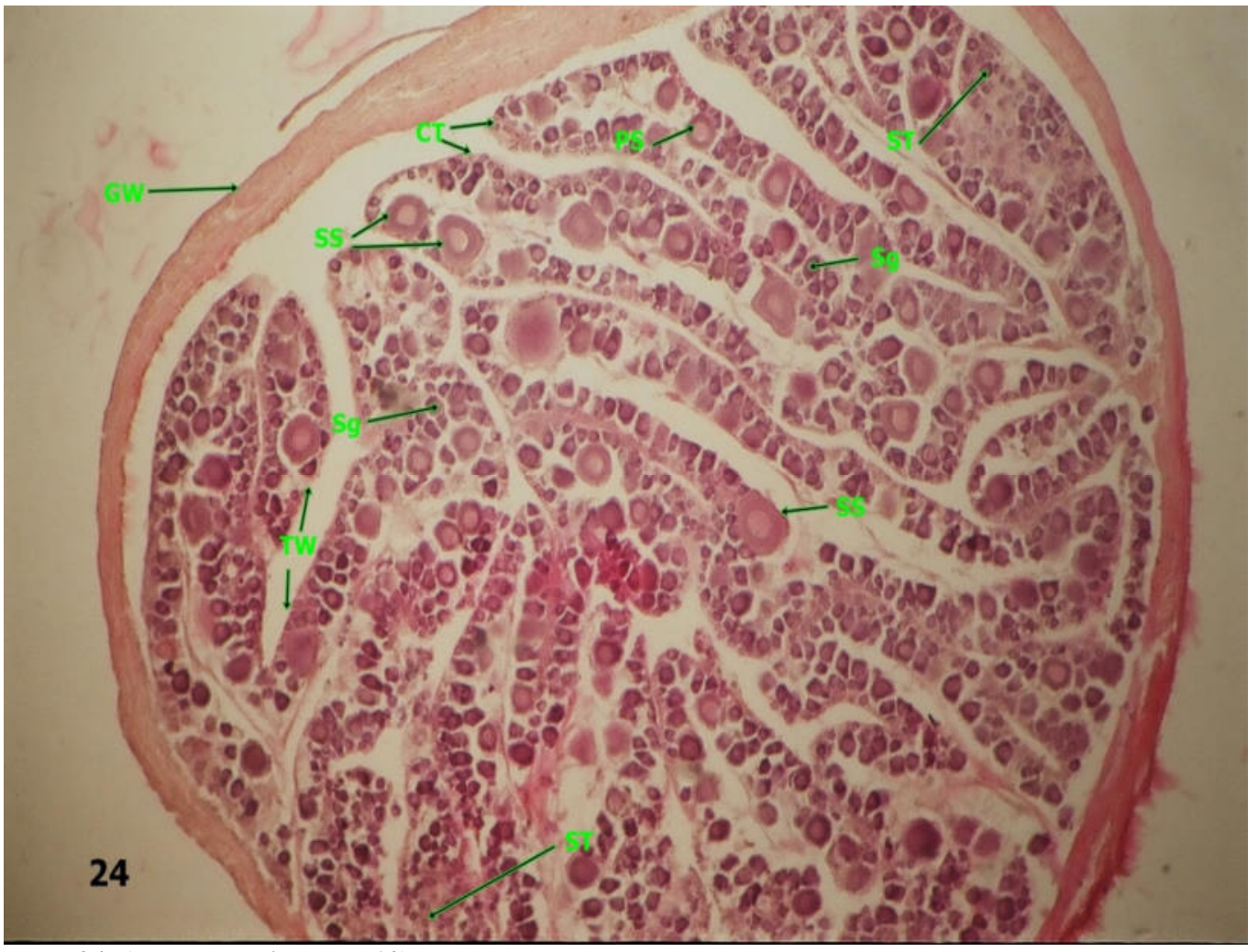

Plate 24 (Whole section, $x=10$ )

Plate (24) transverse section through the maturing testes showing the primary spermatocytes (PS) multiplied and divided to produce the secondary spermatocytes (SS). These cells were formed by the first meiotic division of the primary spermatocyte, the secondary spermatocyte has a short duration and rapidly divided into spermatid (ST). The cell wall of second spermatocytes becomes indistinct. The nucleus is spherical, the chromatin material become either polarized to one pole of the nucleus or deeply condensed with the transluescent centre. In this stage the gonad wall (GW) still thin and testicular lobe comprised of seminiferous fibrous connective tissue (CT), the tubule wall (TW) is appeared (stained with Hematoxyline and Eosin). 


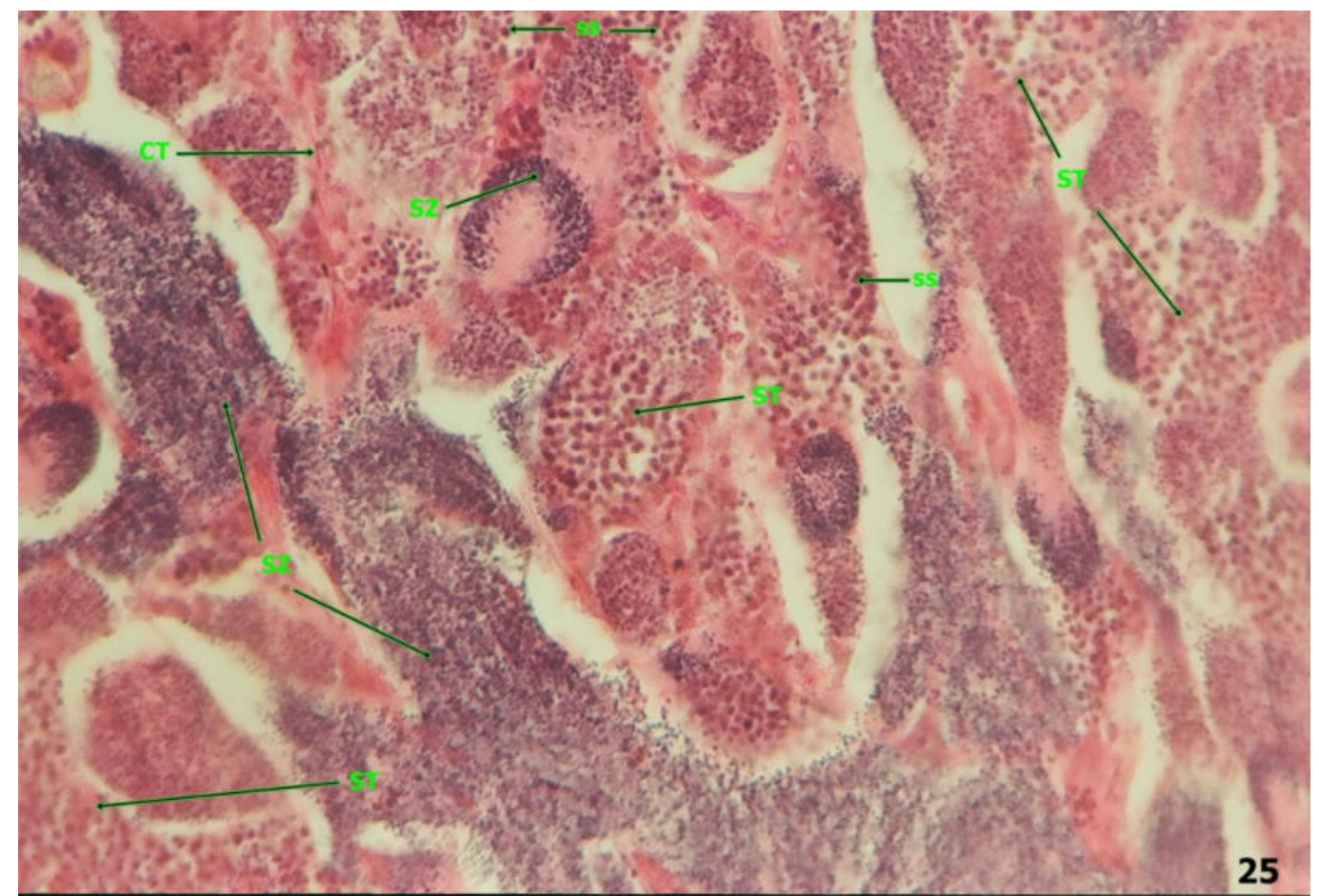

Plate 25 (Whole section, $x=10)$

Plate (25) transverse section through the nearly ripe testes (last maturing) showing active spermatogenesis throughout the testes, nest primary spermatcytes (SP), a nest of secondary spermatocytes (SS). These cells were formed by the second meiotic division of secondary spermatocytes the spermatid (ST) appeared smaller than the primary and secondary spermaticytes are recognized by indistinct cell outlines. According to the degree of maturation, the spermatid is either grouped inside a cyst or distributed throughout the central lumen of the lobules. Spermatid developed to spermatozoa (SZ) at this stage and have many inter lobular connective tissue (CT) and gonad wall become very thin (stained with Hematoxyline and Eosin). 


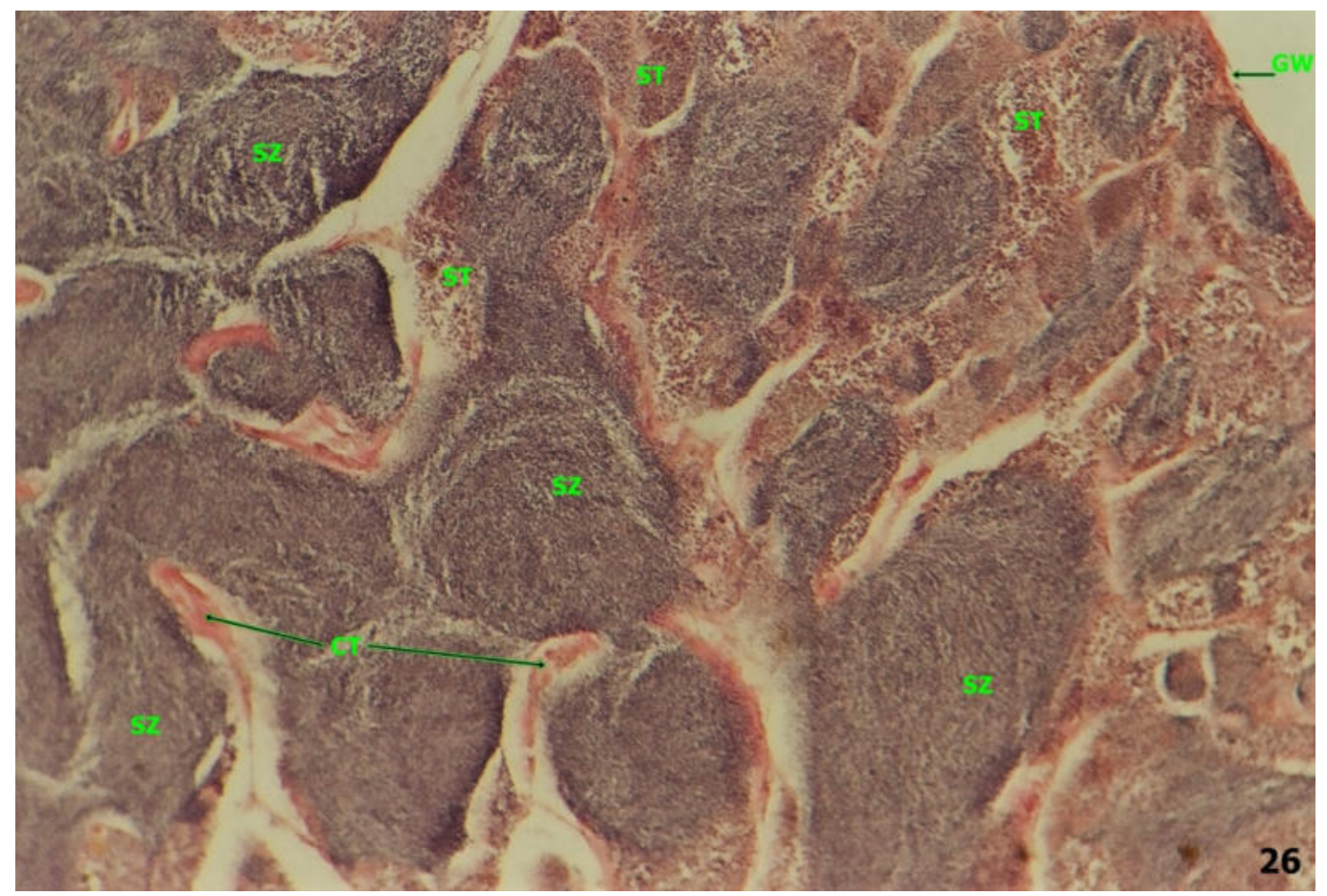

Plate 26 (Whole section, $x=10$ )

Plate (26) transverse section through the mature testes showing degenerative change of the seminiferous tubles expressed by damage of their membranes spermatozoa (SZ), in this stage the spermatid (ST) still appearing and the gonad wall $(\mathrm{GW})$ still very thin. The spermatozoa (SZ) were distinguished by small round heads and slender, elongated tails. The chromatin material was condensed in the head of spermatozoa, the active spermatozoa migrated towards the centre of the lumen of the lobule (stained with Hematoxyline and Eosin). 


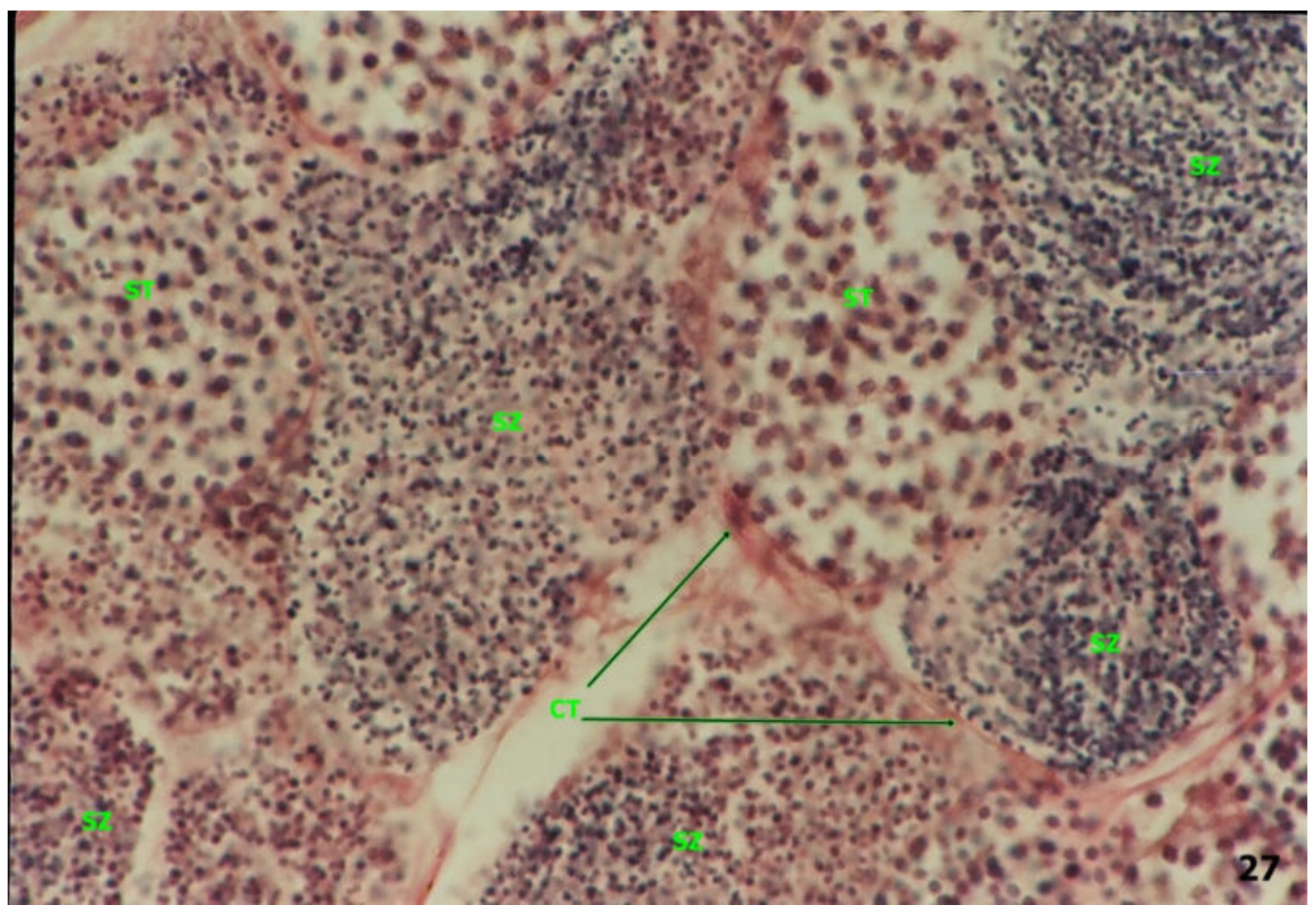

Plate 27 (Whole section, $x=10)$

Plate (27) transverse section through the full mature testes all the lobules is filled with free spermatozoa (SZ), with saw spermatids (ST) at the end of spermiogenesis are visible next to the lobule wall, tubule wall (TW) and connective tissue (CT), (stained with Hematoxyline and Eosin).

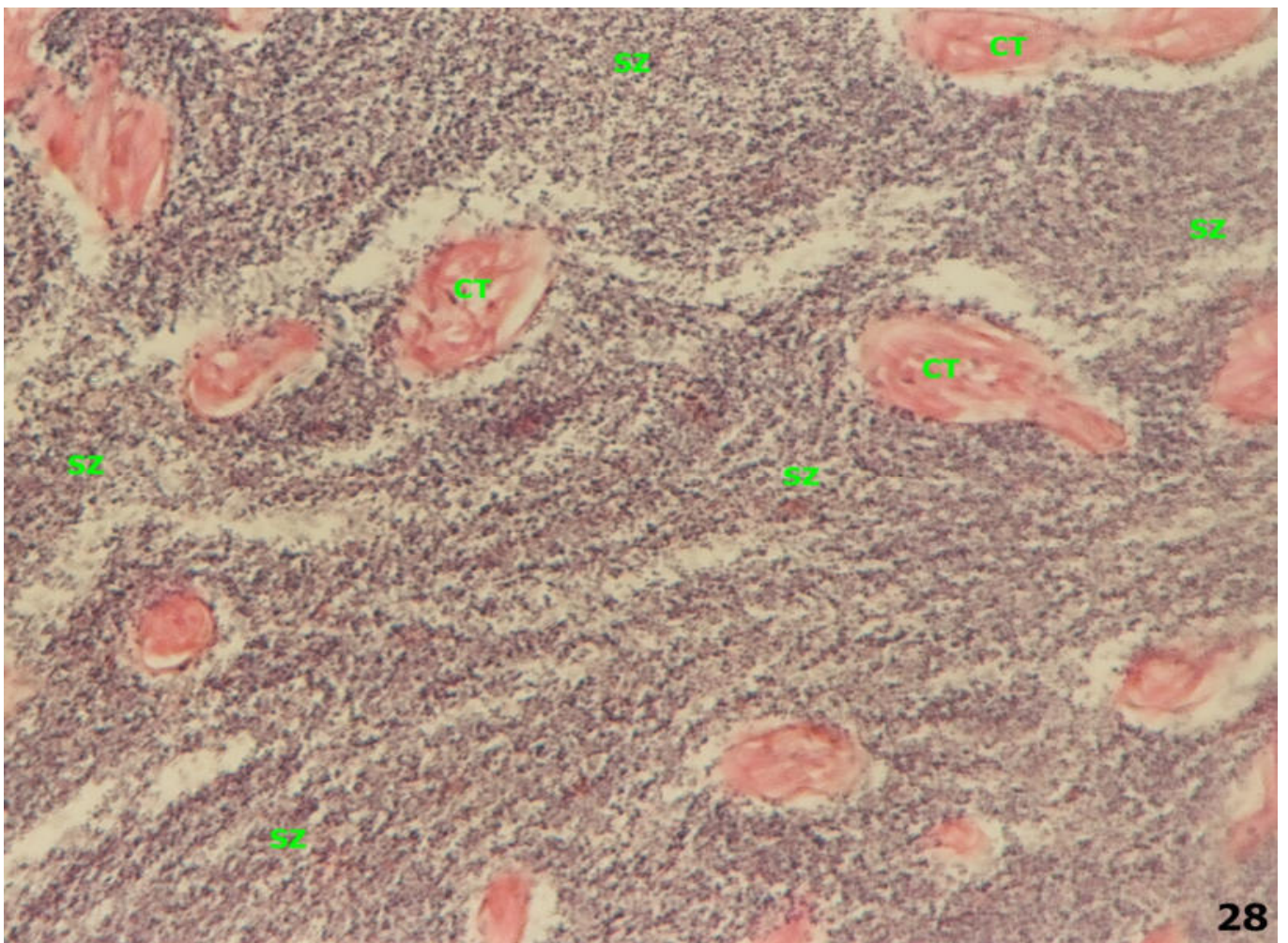

Plate 28 (Whole section, $x=10)$ 
Plate (28) transverse section through the spawning testes (oozing) the all tastes filled with spermatozoa (SZ) and some of connective tissue (CT) or blood vessels. In this stage showing reduction in size of lobules leaving space between them, decrease of the intensity of spermatozoa (SZ), and thick inter lobular connective tissue (CT). The spawning testes were observed most months of the year but peak in other from March until November for $L$. harak (stained with Hematoxyline and Eosin).

\section{Discussion}

Lethrinus harak was economical important fish species, beside its ease adaptability for culture an increasing interest has been given to its propagation and productivity on Red Sea Coast. The gross morphological criteria used to distinguish the six maturity stages assigned to gonad development, together with the cyclical changes shown by the gonad-index, to provide reliable evidence of spawning for Lethrinus harak in shore waters. The occurrence of high percentages of individual fishes with running gonads (stage5) in the samples in, at least, eight consecutive months from October to April and the subsequent emergence of spent fish one month after the October peak through April suggests that L. harak population at the Red Sea coast has a prolonge spawning season extending from October to April with two peaks occurring in October and February.

Unfortunately, no published data on reproduction of $L$. harak are available in the literature. However, the information available for other lethrinid species can be used for comparison. Wassef \& Bawazeer (1992) found that the longnose emperor, L. elongatus, in the Red Sea has a protracted spawning season spanning four months (May-August). Kuo \& Lee (1990) reported that the common porgy, L. nebulosus, also has a prolonged spawning season extending from September to February in the Northwestern Shelf of Australia. Nzioka (1979), examining the gonads of East African reef fishes, postulates two spawning seasons for some lethrinid species in September/ October and January/February.

The present data and histological study on length and age at first maturity for L. harak showed the male and females attain first sexual maturity (fish in stage 2 of gonad development and above were considered mature). It was found that fish lengths smaller than $19.5 \mathrm{~cm}$ and $18 \mathrm{~cm}$ are always immature. The first sexual maturity at 21.5 $\mathrm{cm}$ for males, and $22.5 \mathrm{~cm}$ for females both sexes at the second year for life. These findings are in general in agreement with Ntiba., et al (1995) in study of L. harak in Kenyan water; Shakeel and Ahmed (1996) stated that, the minimum size allowed to be caught for E. areolatus in Malé, Maldives is $25 \mathrm{~cm}$. McIlwain et al. (2006) in their study on L. nebulosus in the Arabian Sea, Sultanate of Oman found that, the immature individuals constituted more than $40 \%$ of the that, the age at first maturity of L. nebulosus was 1.58 year which corresponds to length 29.5 $\mathrm{cm}$ in the coastal areas of Mauritius. The length at first sexual maturity of $L$. nebulosus in Arab Emirates in front of Abu Dhabi was determined by Grandcourt et al. (2003), as $28.6 \mathrm{~cm}$ for males and $31.3 \mathrm{~cm}$ for females. While, Grandcourt et al. (2006) found that, the length at first sexual maturity of L. nebulosus in the Southern Arabian Gulf was $27.6 \mathrm{~cm}$ for males and $28.6 \mathrm{~cm}$ for females.

The Plates (from 1 to 17) show the histological changes (development) in ovaries during the reproductive cycle for the females of L. harak. Oogenesis in fish are known to undergo a sequence of external and internal changes, these changes in the oocytes development have been detected in various fish species. According to various authors, the course of development of oocytes have been divided into stages, phases or periods in order to differentiate the gradual changes in their peculiarities (Guraya et al. 1975 \& Matsuyama et al. 1991).

It is well known that the growth of oocytes takes place at two development phases namely the primary growth phase and secondary growth phase (i.e. vitellogenic oocyte). The primary growth phase two species under the present study includes only an immature oocyte which can be divided into three subdivision or phases. Initially, the early young oocyte characterized by having a large nucleus containing one large nucleolus. The early stage of young oocyte species under the study is similar to prematuration period. These results are in agreement with Zaki et al. (1986), synapsis - period of Latif and Sandy (1973), immaturation period of Assem (1992 and 1995) and chromatin - nucleolus stage of El Gamal (1997) on Cyprinus carpio study. The late immature oocyte stage of the present study characterized by increasing oocyte in size and the nucleoli mostly located towards the nuclear membrane. The late immature stage of the present study is similar to protoplasmic growth of Latif and Sandy (1973) and the perinucleolus stage of Mousa (1994 and 2002) and El Gamal (1997) on Cyprinus carpio study.

In the present results, the perinucleolus stage undergoes a gradual increase in the oocyte size and in number of nucleoli of the nucleus. During the late perinucleolus stage a basophilic organelle appears in the cytoplasm (yolk nucleeus). The yolk nucleus can be termed as, achroplasm, crop vitelline or Balbiani bodies (Zaki, et al., 1991).

The second growth phase (i.e. vitellogenic oocyte) includes vacuolization of cytoplasm and yolk deposition. In 
some other teleosts, the vitellogenic stages were divided into phases vacuolization and yolk deposition as described by Zaki et al., (1986) and Ashour et al. (1990). However, in some other fishes, there were four stages: vesicle stages, primary yolk granules stages, secondary yolk granules stage and tertiary yolk granules stage as described by (Khoo, 1979; Mousa, 1994 and 2002 and El Gamal 1997) on the ovary of many other fishes. On the contrary of many other fishes, the yolk depositions first appeared in the peripheral cytoplasm, thereafter scattered towards the center of ooyte as those described by (Zaki et al., 1986; Zaki and El Gharabawy 1991; El Gamal, 1997 and Mousa, 2002).

Recent electron microsccopical studies revealed that the yolk nucleus was not a homogenous structure, and it was composed of various cellular organelles such as mitochondria, smooth endoplasmic reticulum, multivesicular bodies and lipid granules (Wallace and Selmon, 1981). At the end of the perinucleolus stage and at the vesicles stage the follicular epithelium appeared surrounding the oocytes. On further growth of oocytes, these follicular epithelial cells formed a layer coating the oocytes.

It was believed that the prementioned follicular cells play an important role in active transport of proteins and other nutrients from blood to oocytes during vitellogenesis as reported by Norrevang (1968). Guraya et al., (1975) claimed that follicle cells and oocytes are considered to play an important role in the cytoplasm structures was proved to synthesize sexual steroids by follicular theca envelope. In the present study the zona radiata layer contains microvillar processes pass through pore canals. The microvilli are thought to be the site of substance exchange between the follicle cells and the oocyte (Mastsuyama et al., 1991).

For the nearly ripe stage the present results revealed the presence of few spermatogonia and spermatocytes showing moderate quantity of spermatozoa. These results confirm with most teleosts as reported by Ghabrial (1990) and El-Gohary (2001) in Oreochromis nilotica. Ripe stages show a markeds dilation of seminiferous lobules containing a lot of sperms. Also the present study revealed that the spawning stage similar to the ripe stage show a decrease in the size of lobules due to discharge of considerable amounts of spermatozoa. This stage extended through the period of many months through the year for L. harak.

The complication of the process of spermatogenesis and the character of the discharge of the sexual products are relative to the asynchronism in the reproduction of the primary spermatocyte as reported by Koppel (1955). Also this asynchronism may be due to the progress of spermatogenesis wave along the different parts of the testes (Butskaya-1955). Adaptation of prolonged and continuous spawning is characterized by fractional discharge of the sperm cells. The prolonged spawning is enhanced by the presence of different individual caught at the same period exhibit different spermatogenic activities and the spermatozoa are discharged gradually from the semineferous lobules and the reduced size of testes, so the specific characteristic of spermatogenesis is related to the type of spawning depending on the character of spawning in female (Zaki et al., 1986; Assem, 1999 and El-ghamaly, 2001).

\section{Conclusion}

The results of the first length and age of maturity for the $L$. harak was extremely at the $21.5 \mathrm{~cm}$ for males and 22.5 $\mathrm{cm}$ for females both sexes at second year.

The histological and morphological characters of ovaries L. harak have indicated that the oocyte pass through six successive stages of sexual maturation stage 1, immature oocyte (resting stage); stage 11, Vacuolization of the cytoplasm (preparatory stage); stage 111, beginning of yolk deposition (maturing stage); stage 1v, nearly mature (last maturing); stage $\mathrm{v}$, the maturation of oocytes (spawning stage) and stage v1, egg resorption (postpawning stage).

Acknowledgement: Authors acknowledge Sayed Yosif from Khartoum University for photo the slides and the Faculty of Marine Sciences and Fisheries, Red Sea University.

\section{References}

Abu Gideiri,Y. B. (1984) Fishes of the Sudan. Khartoum University press. 166p.

Abu Degoon, A. S. A. (2005). On some Biological Aspects of the sky emperor Lethrinus mahsena (pieces, Forsskal, $1775)$ in the Sudanese Red Sea Waters. M. Sc. Thesis. Department of Fisheries Science, University of Juba. pp.102.

Ashour, M.B; Zaher, M.M. and Rida, S. (1990). Ecological studies on female reproductive cycle of some fishes of 
the River Nile at Beni suef area III. Histological studies of the seasonal cycle of the ovary of Chrysichthyes Auratus. J. Egypt. Ger. Soc. Zool.,2: 287-297.

Assem, S.S.(1992). Reproductive Biology and physiology of one species of family Sparidae in Mediterranean sea. M.Sc. Thesis, Faculty of science, Alexandria, Egypt.

Assem, S.(1995). Reproductive physiology and induced spawning of Selea species. Ph.D. Thesis, faculty of science, Alexandria University, Alexandria, Egypt .

Assem, S.S. (1999). Reproductive Biology, spermatogenesis and ultrastructure of testes Caranx cyrsos . Bull. Nat. Inst . Of Ocean. \& Fish. A. R.E. 25:311-329.

Butskaya, N.A. (1955): On the peculiarities of functions of testi in fishes with different type reproduction. Akad. Nauk. USSR, 100(4):809-812.

EI Gamal, A.A. (1997). Biological studies on the reproduction of the gilthead bream, Sparus aurata, reared in fish farms. PhD. Thesis of Science, Mansoura University, Mansoura, Egypt.

EI Gahamdi, F (2001). Reproductive Biology and physiology of Acantobagrus Bfisciatus in Red Sea Jeddah Region M.Sc Thesis. Girls College of Education scientific department. El-gohary, N.M (2001). The effect of water quality on the reproductive biology of Nile Tilapia Oreochromis niloticus in Lake Manzalah. Ph.D. Thesis, Faculty of science, AinShams University.

Ebisawa, A. (2006). Reproductive and sexual characteristics in five Lethrinus species in waters off the Ryukyu Islands. Ichthyological Research 53: 269-280.

Grandcourt, E.M., F. Francis, A.T. Al Shamsi, K. Al Ali and Al Ali, S. (2003). Stock assessment and biology of key species in the demersal fisheries of the Emirate of Abu Dhabi. Marine Environmental Research Centre, Environmental Research and Wildlife Development Agency, Project no. (02-23-0001).

Gghabrial, S. G. (1990). Induced spawning and developmental criteria of two Oreochromis spp. And their hybrid. M.Sc. Thesis. Alexandria University.

Guraya, S.S Kaur, R. and Saxena, P.K (1975). Morphology of ovarian changes during the reproductive cycle of the fish ,Mystus tengara (Ham). Act. Anat., 91:206-222.

Hilborn, R. and C. J. Walters.(1992).Quantitative Fisheries Assessment Choice, Dynamics and Uncertainty. New York: Chapman \& Hall.

Hunter, J.R., B.J. Macewicz, N. C. H. LO., and C. A. Kimbrell. (1992). Fecundity, spawning, and maturity of female Dover Sole, Microstomus pacificus, with an evaluation of assumptions. Fish. Bull., U.S., 90: 101128.

Koppel, E (1955): Untersuchungen uber die mannlichen fortpflanz -unsorane des Karpfens Cypninus carpio L. Zeitscher. Fisheries, 4:42-481.

Khoo, K.H.(1979). The histochimistry and indocrine control of vitellogenesis in goldfish ovary. Can. J.zool.,57:617-6 26.

Kuo, C. L. \& Lee, S. S. (1990). Maturation and spawning of common porgy, Lethrinus nebulosus (Forsskål) in the Northwestern Shelf of Australia. J. Mar. Biol. Assoc. India. 32: 201-207.

Kraus, G., J. Tomkiewicz, and Koster, F. W. (2002). Egg production of Baltic cod in relation to variable sex ratio, maturity and fecundity.

Can. J. Fish. Aquat. Sci., 59: 1908-1920.

Lassi, F. (2003). Age, growth, mortality rates and reproductive biology of three Fijian emperor fishes (Pisces: Lethrinidae): Lethrinus harak Forsskal, 1775, Lethrinus obsoletus Forsskal, 1775, and Lethrinus atkinsoni, Seale, 1910. School of Pure and Applied Science, University of the South Pacific, Fiji. MSc. Thesis. 204 p.

Loubens, G. (1980). Biologie de quelques espèces de poissons du 09 lagon Néo-Calédonien. II. Sexualité et reproduction. Cah. Indo- Pac. 2(1):41-72.

Loubens, G. (1980). Biologie de quelques espèces de poissons du 09 lagon Néo-Calédonien. II. Sexualité et reproduction. Cah. Indo- Pac. 2(1):41-72.

Latif A.F.A and Saady, B.E. (1973). Reproduction of the Nile Bolti Tilapia nilotica L. Bull. Nat. Inst. Of Ocean. \& Fish. A.R.E 3:117-142. 
Latif, A. F. A. and Saady , R.E.(1973). Oogenesis in the Nile Bolti , Tilapia nilotica. Bull.Inst.Ocean .And Fish., Egypt,3: 183-202

Matsuyama, M.; Nagahama, Y. and Matsuura S. (1991). Observation on ovarian follicle ultrastructure in the marine teleost, pagrus major, during vitellogenesis and oocyte maturation. Aquaculture, 92:67-82.

McIlwain, J., G.V. Hermosa, M. Claereboudt, H.S. Al-Oufi and M. Al-Awi, (2006). Spawning and reproductive patterns of six exploited finfish species from the Arabian Sea, Sultanate of Oman. J. Appl. Ichthyol., 22: 167-176.

Ntiba, M. J., Kulmiye, A. J and Kisia, S. M.(1995). Some Aspects of the Reproductive Biology of the Thumbprint Emperor, Lethrinus harak (Forssk.1, 1775), in Kenyan Coastal Waters. Western Indian Ocean J. Mar. Sci. Vol. 1, No. 2, pp. 135-144.

Norrevang, A. (1968). Electron microscope morphology of oogenesis. Int. Rev. cytol., 23:113-186.

Nzioka, R. (1979). Observations on the spawning seasons of East African reef fishes. J. Fish Biol. 14: $329-342$.

Pauly, D. (1994). On the sex of fish and the gender of sientists: collected essays in fisheries science Chapman \& Hall, London; New York .

Soondron, S.; Venkatasami, A. and Mamode, A. (1998). Some results of the study on sexual maturity of Lethrinus mahsena from Saya de Malha Bank. Albion Fisheries ResearchCenter Mauritius.

Shakeel, H. and Ahmed, H. (1996). Exploitation of reef ofresources, grouper and other food fishes. Workshop on Integrated Reef Resources Management, male Maldives.

Wallace, R.A. and Selman, K. (1981). Cellular and dinamic aspects of oocyte growth In teleosts. Am. Zool., 21: 325-343. Fish. 31: 123-132.

Wassef, E. A. \& Bawazeer, F. (1992). The biology of Lethrinus elongates Val., 1830 (Teleosts: Lethrinidae) in the Red Sea. Bull. Natl. Inst. Oceanogr. Fish. Alex. 16: 103-124.

Zaki, M. I.; Dowidar M. N. and Abdalla, A. (1986). Reproductive biology of Clarias gariepinus (Syn. Lazera) Burchell (Claridae ) in Lake Manzallah, Egypt.I.Structureof the ovaries.Folia Morphologica,

XXXIV (3):301-306.

Zaki, M.I. and EL-Gharabawy ,M. M. (1991). Histological characters of ovaries of Mugil capito, (Egypt) . J. Appl. Sci ., 6(6) : 13-23. 